http://jgarmianuniv.net

https://doi.org/10.24271/garmian.39

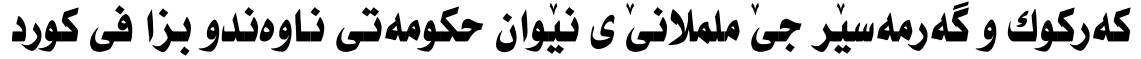 على احمد حسن

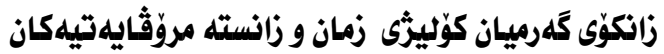

( يا كهركوك و خانهقين يا تا ماوين دهجهذنكيز، وتلهى بلهيخّز مام جه لال )

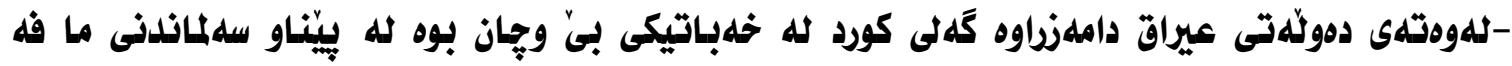

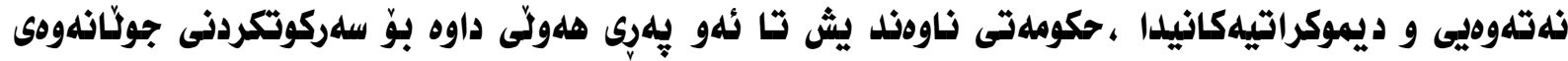

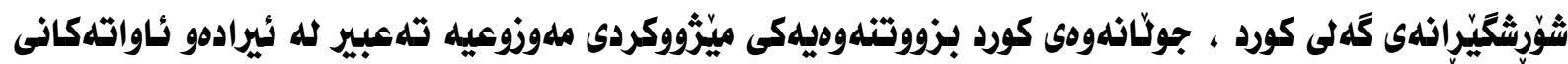

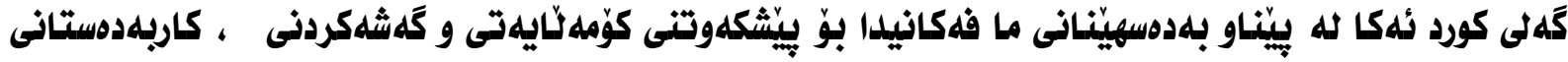

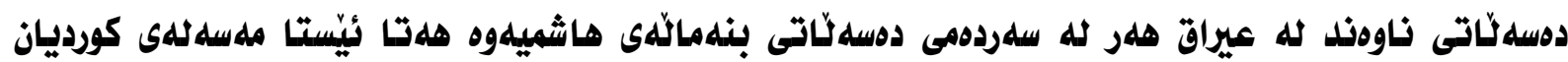
بلهناهله و نارهوا به يلهكيك له كرنكترين تُلهو خهتهرانه له قهلّهم داوه كه هلهرهشه لله عيراق ونهتهوهو نيشتمانى

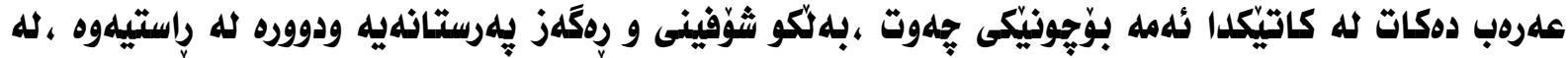

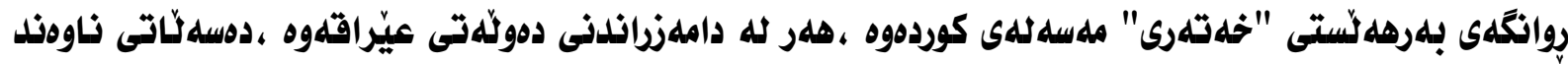

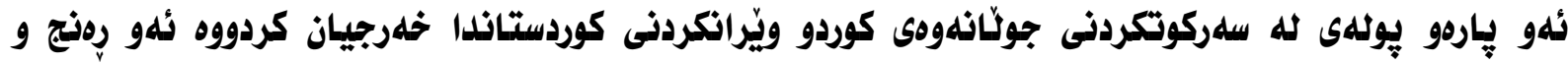

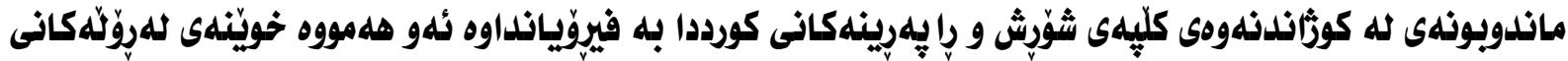

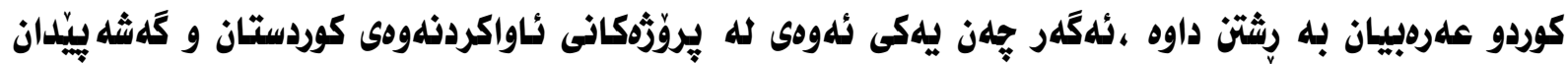
وبيّشخستنيلا و سوشتى جوانى كوردستاندا خهرج بكردايه نيستا هلهم عيّراق و هلهم كوردستان له بـارو زروفيّى ترو

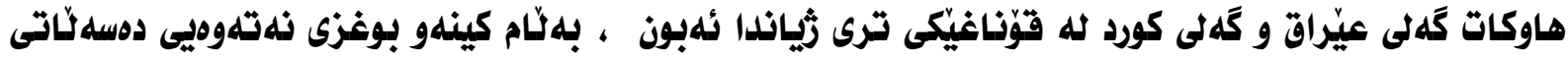

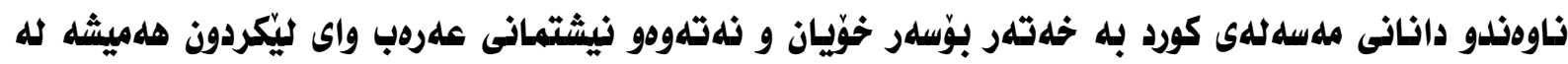

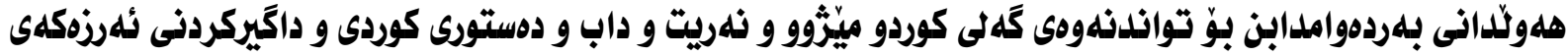

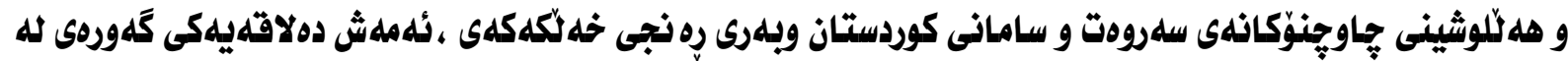

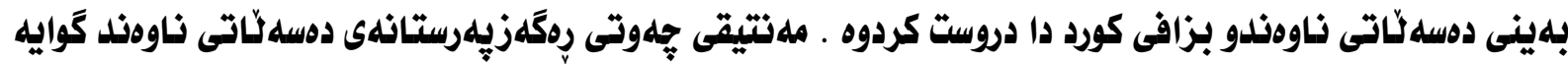

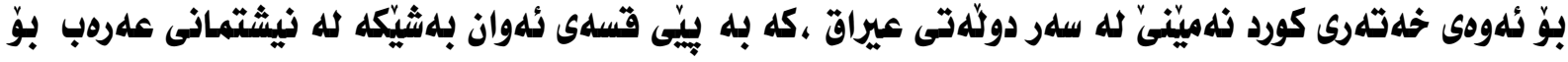
: ألهم مهبلهستهلش :

- ديان هلهزار خيّزّانى كوردى فهيلييان له عيراق دهركردو سلهروهت و سامانيان زهوت كردن - دهيان هلهزار خيّزّانى كورديان للهو ناوجانه دهركرد كه تئكهلّاون لله كوردو توركمان و عهرهب و ، عهرهبيان هينّايه جيَّايان

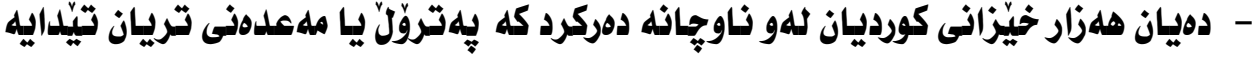

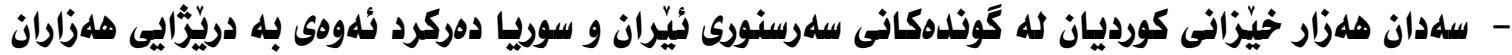

سالّ له بـاخ و رهزو نـاوهدانى بنياتيان نابو تيكياندا 


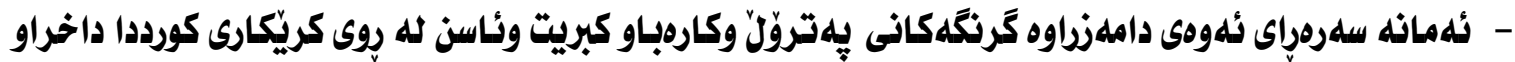

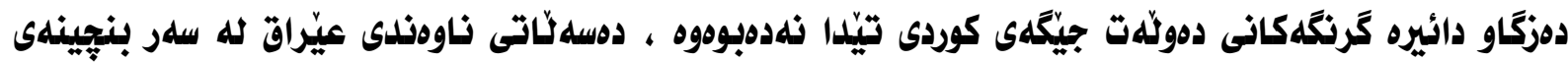

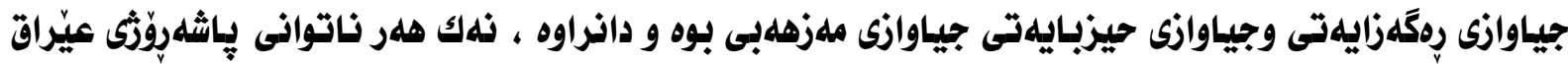

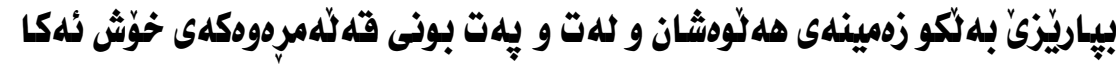

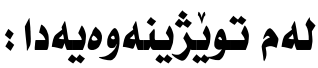

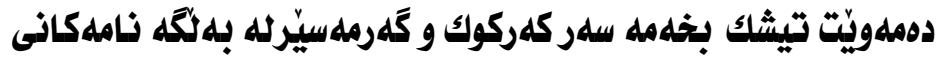

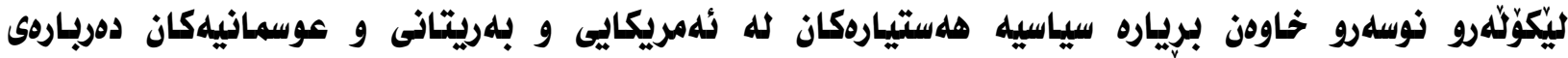

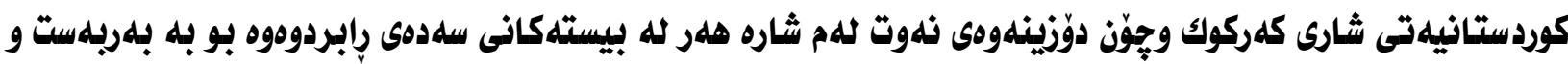

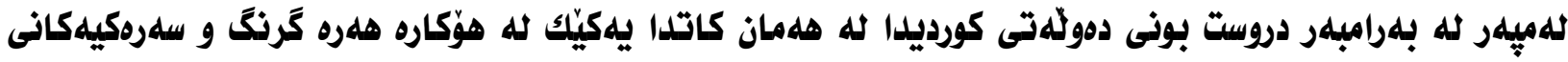

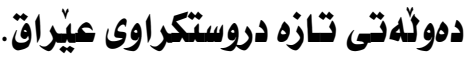

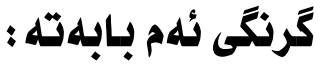

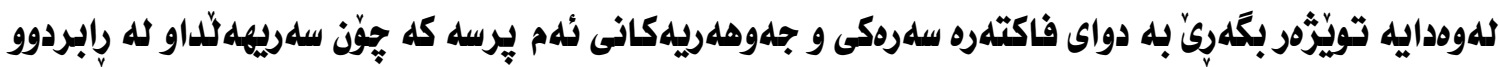

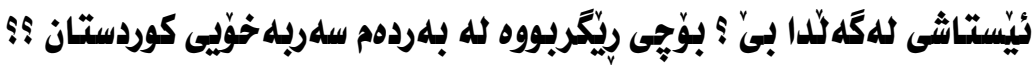

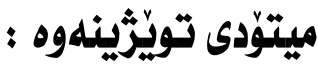

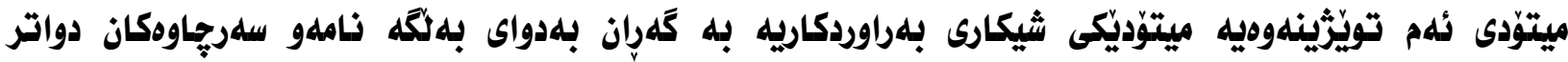

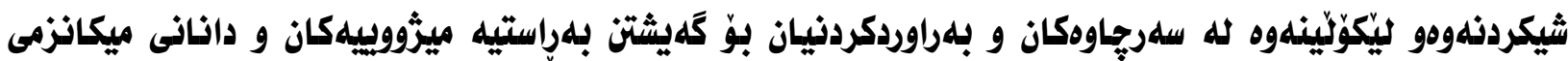

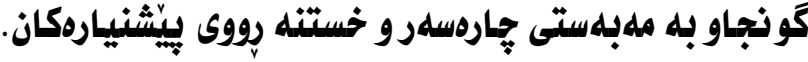
كيّشهى تويّرثينهوه:

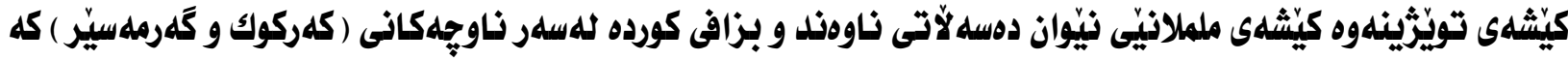

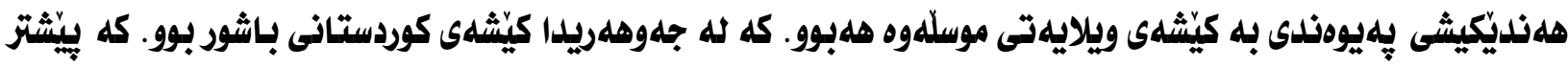

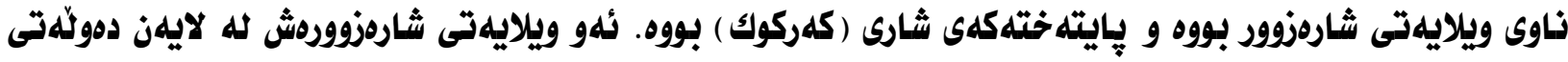

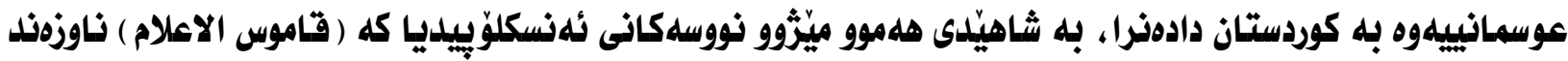
كرابوو.

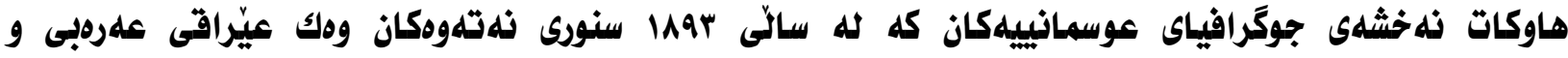
ويلايهتهكانى شام به دهستى عوسمانييهكان خوّيان سنورى ويلايهتى موسلّ و ثاردزوور نووسراوه كوردستان، كه ثنارى موسلّ و كهركوك دهكهويتّه ناو سنورى كوردستانهوه. 


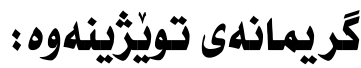

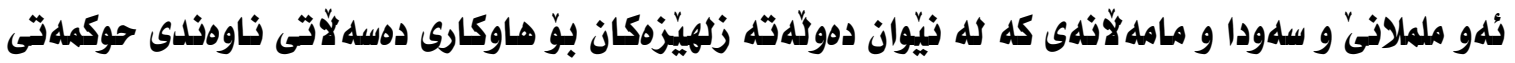

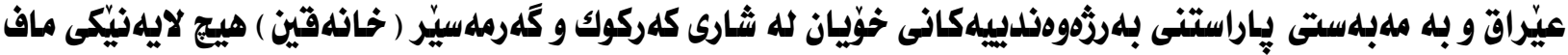

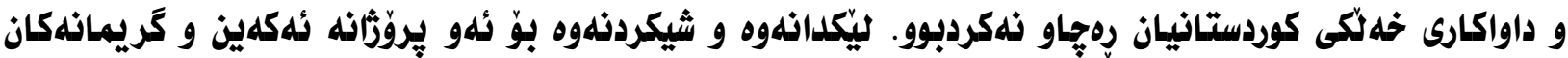

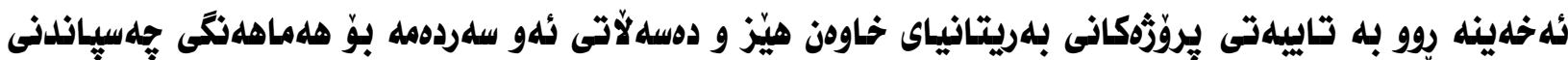
سيستهمى ناودنلى لله عيُراق و يُشتكِيرى حوكمهتى تازه داملزراوى عيرّاق.

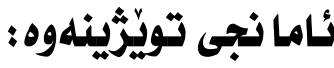

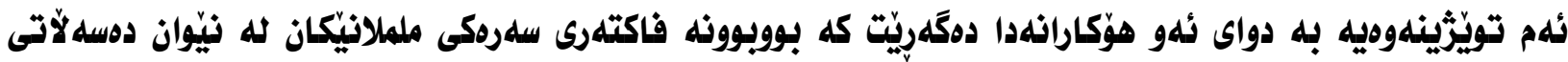

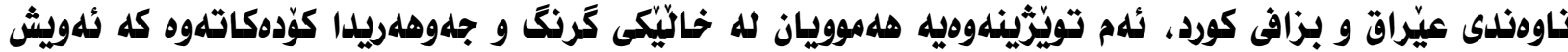

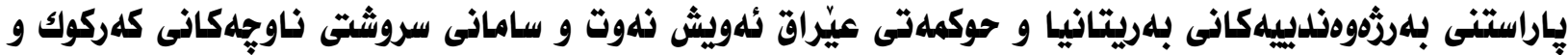

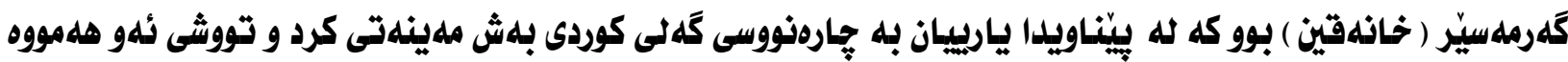
مالَ ويُرانى و كاولكارييهيان كرد.

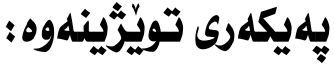

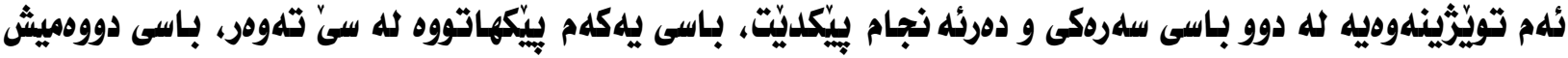

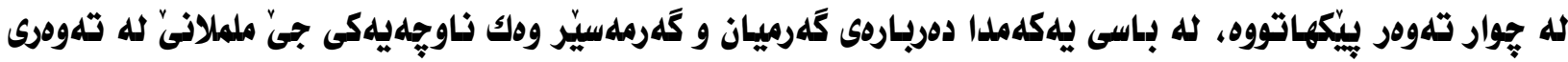

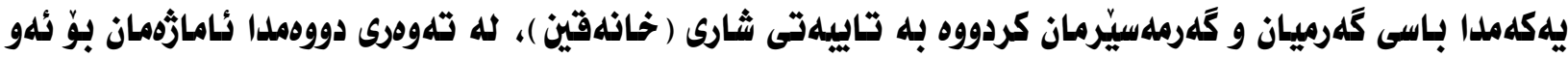

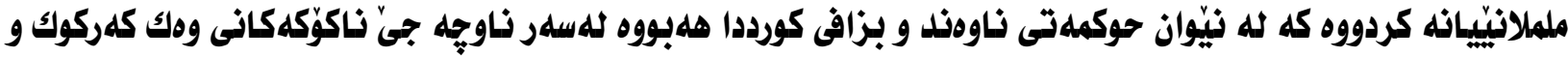

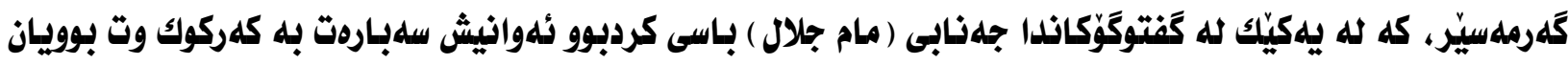

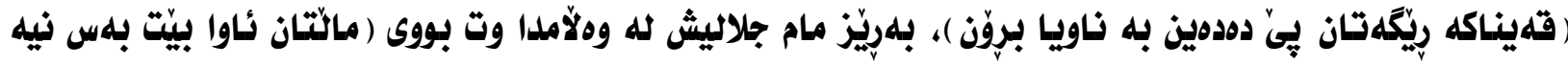

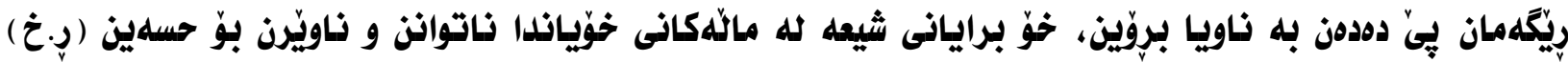

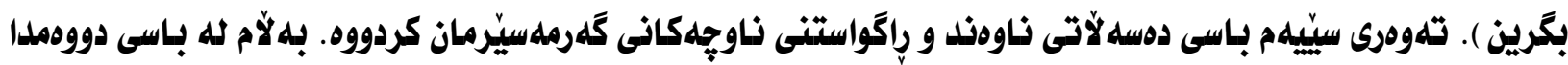

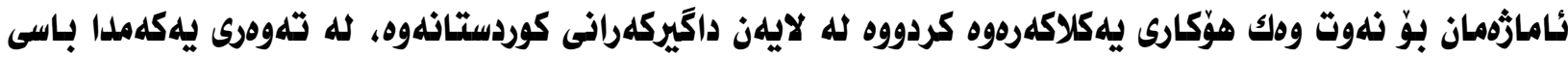

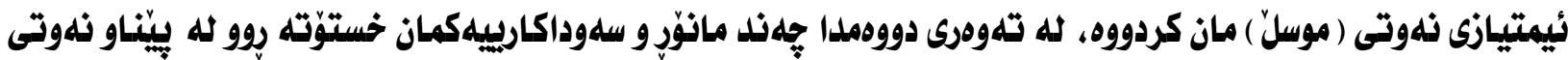

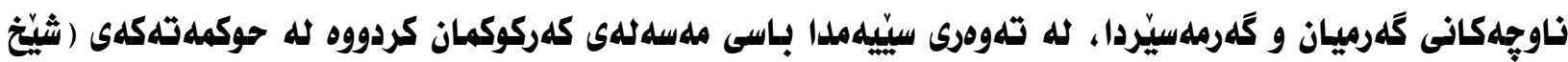

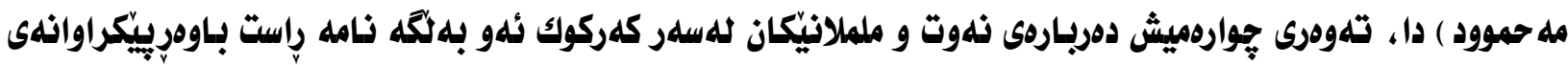

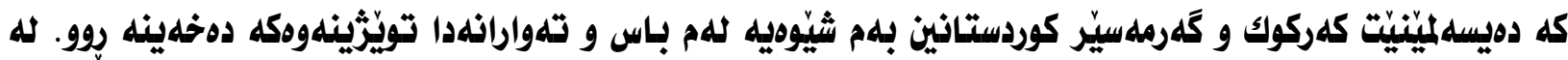
كوّتايثلا دهرئه نجامهكان ديارى دوكلين. 


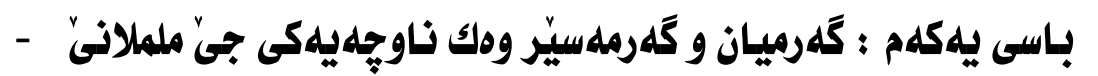

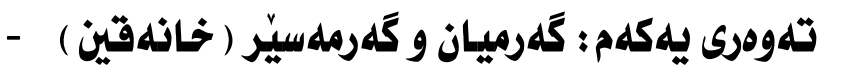

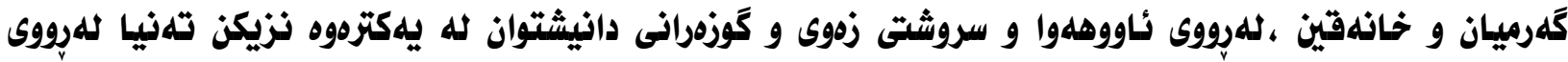

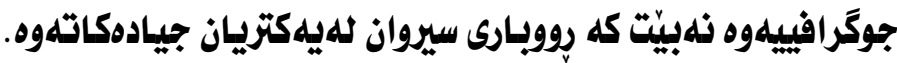

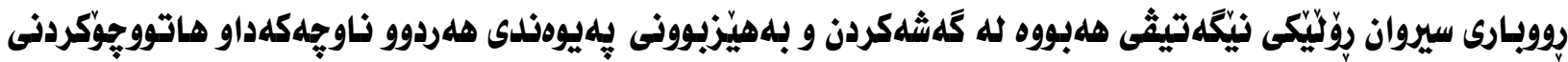
نيّوانيانى به تاييهت لله ودرزى زستان و به هاردا درواركردووه.

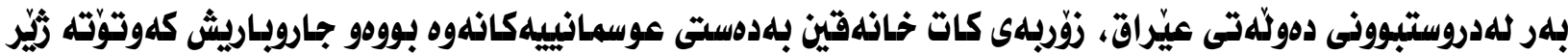

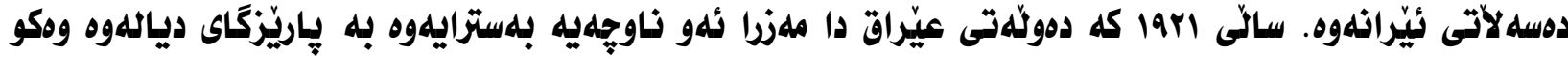

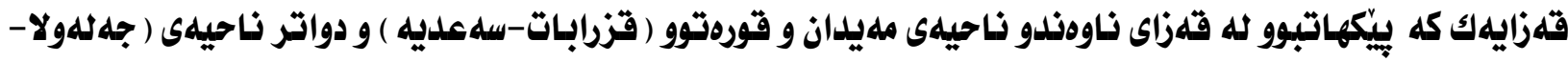

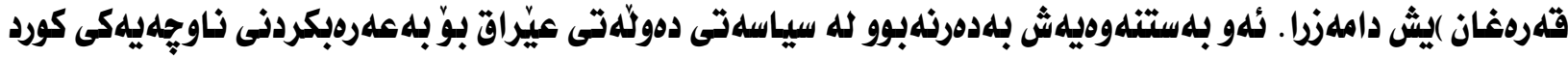
نشينى ودك خانهقين.

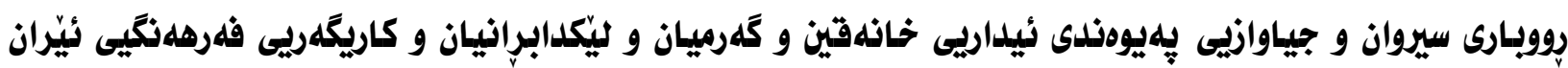

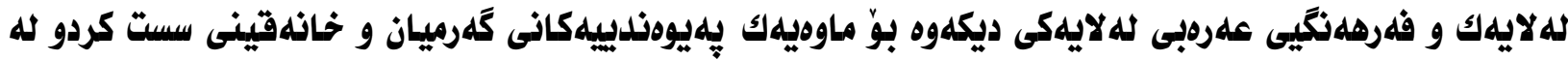

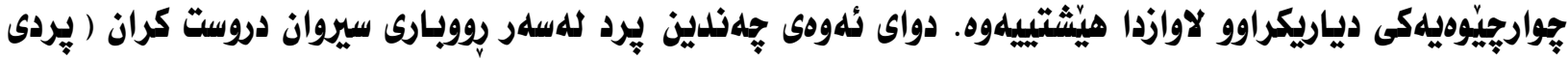

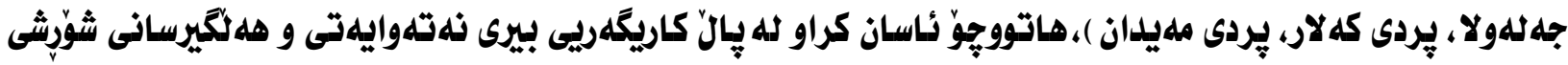

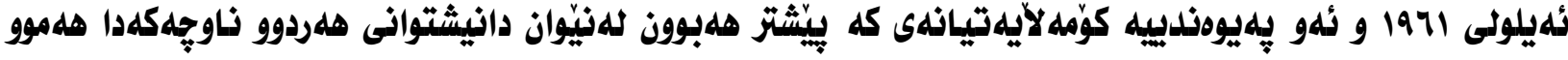

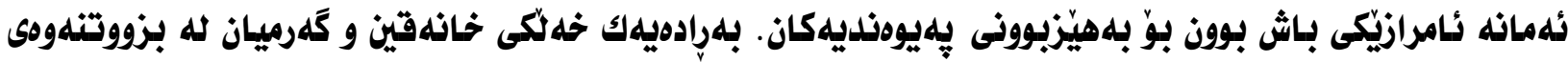

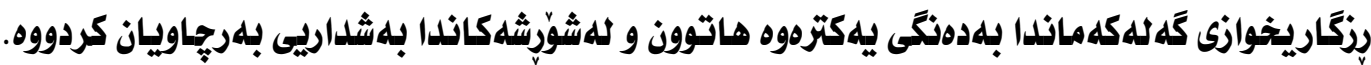

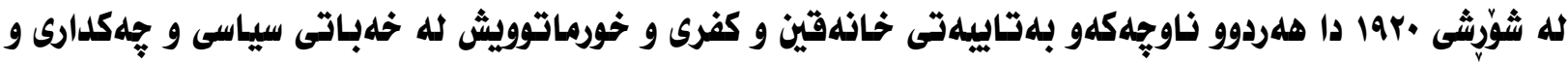

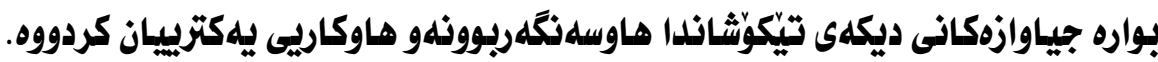

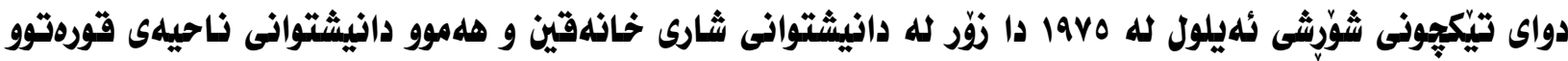

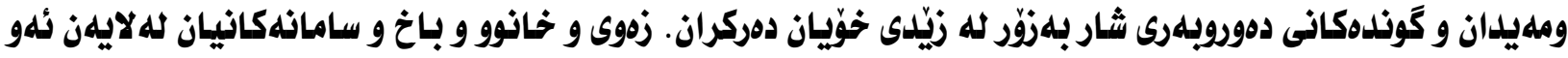

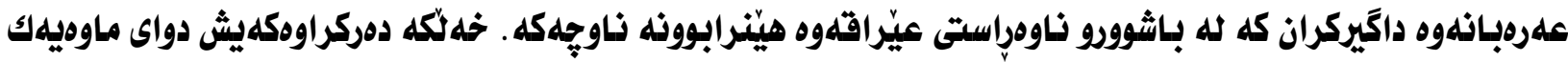

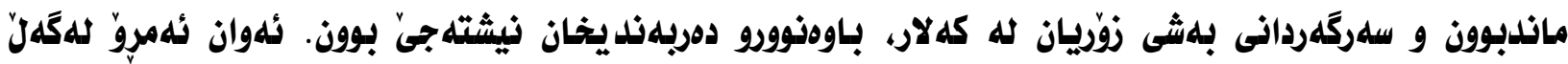

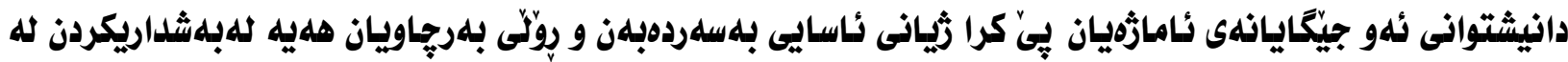

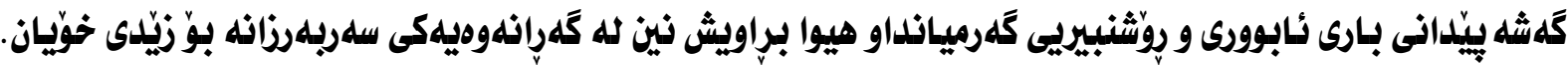

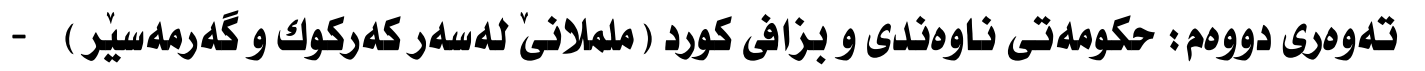

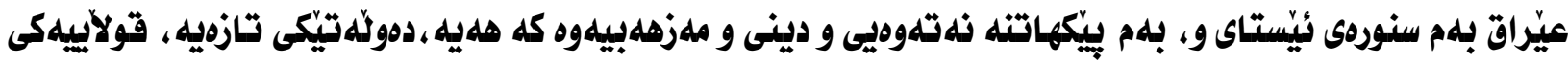

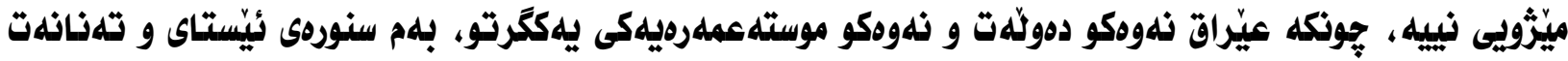

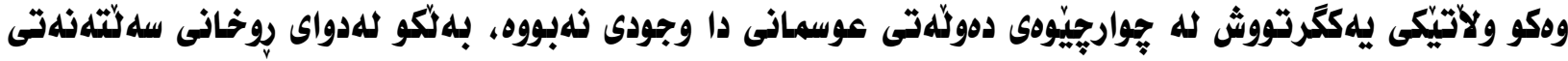




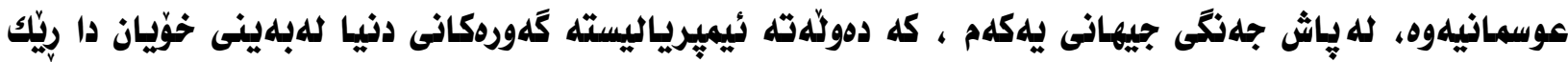

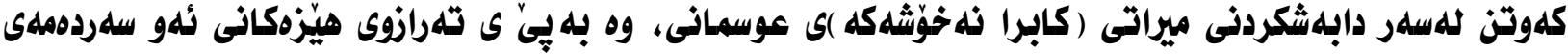

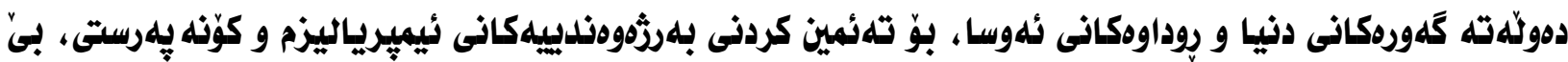

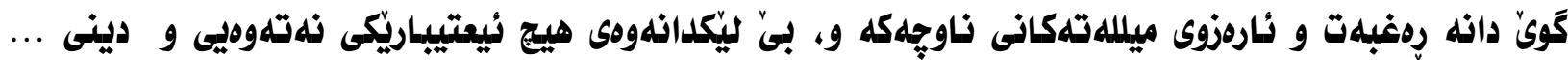

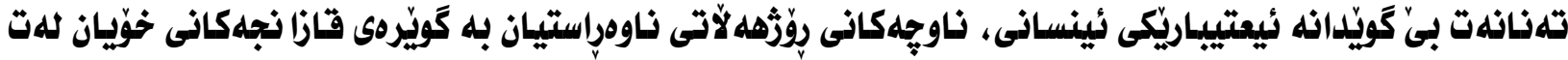

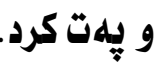

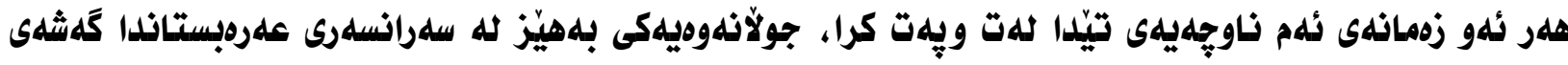

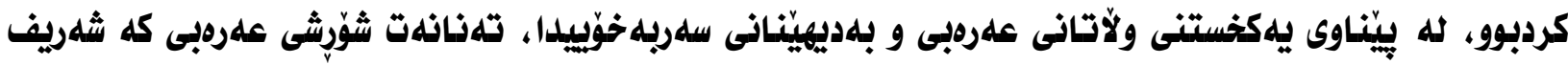

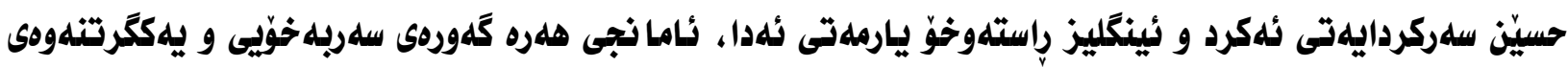

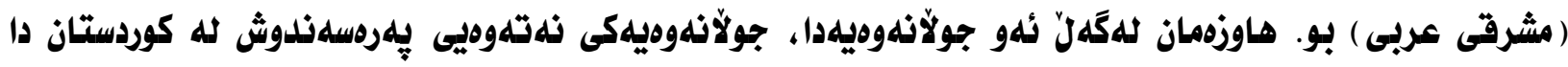

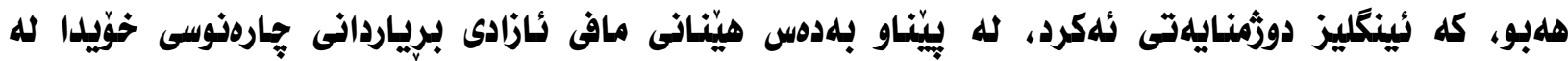

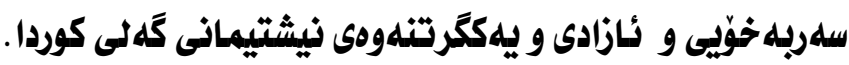

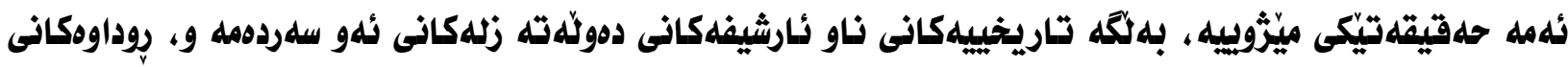

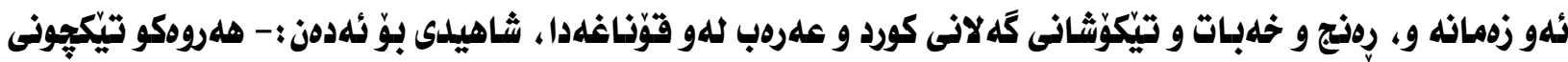

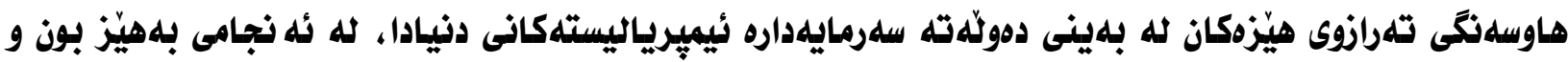

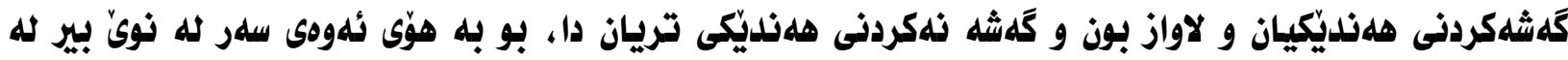

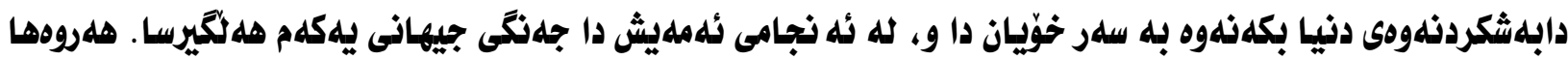

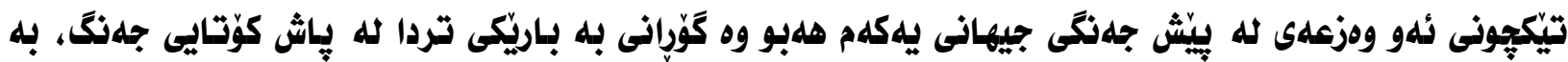

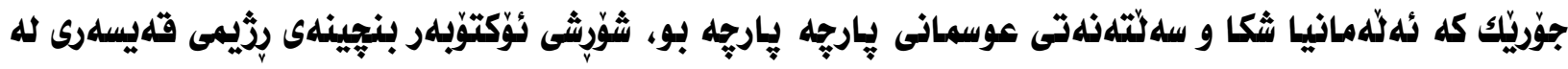

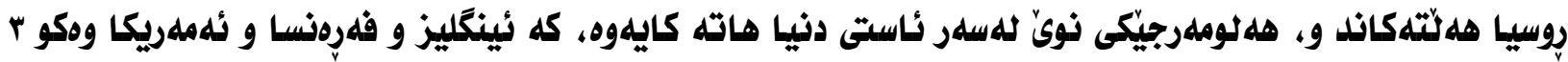

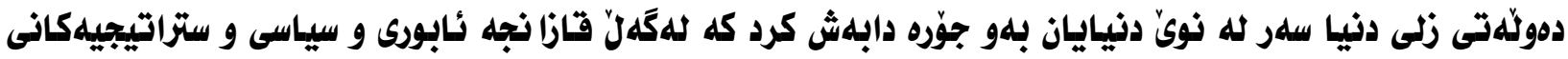

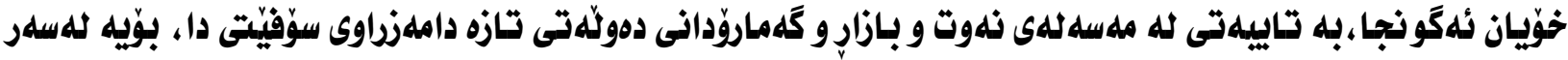

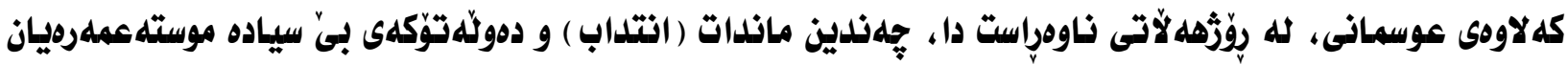

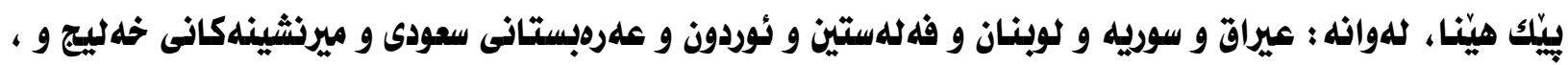

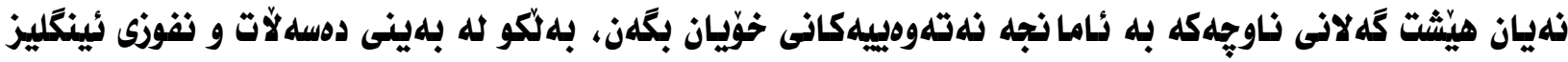

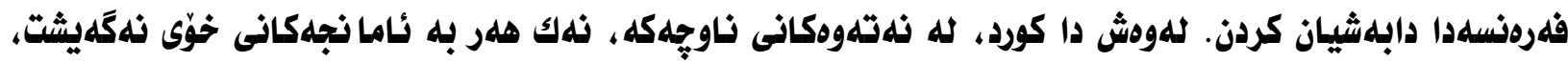

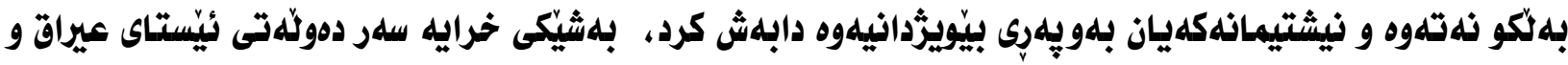

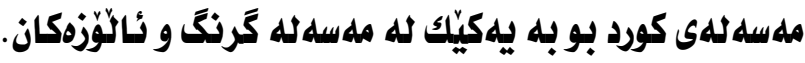

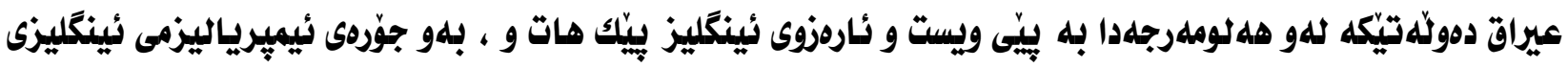

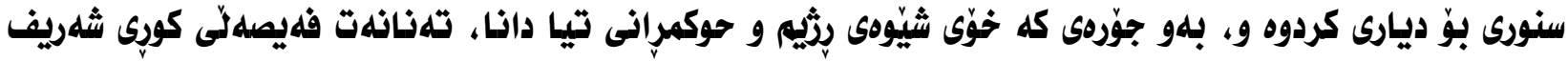

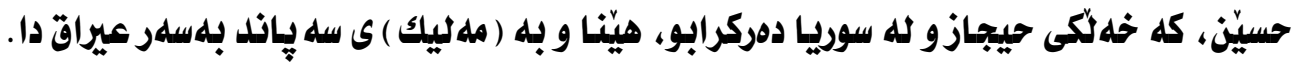




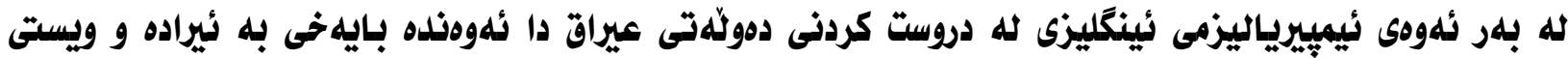

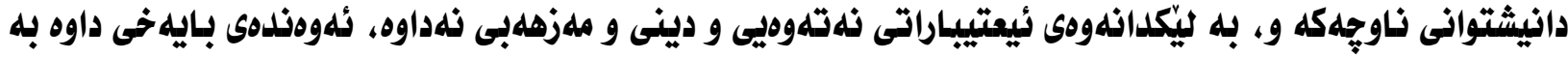

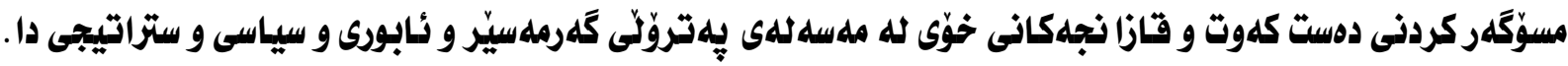

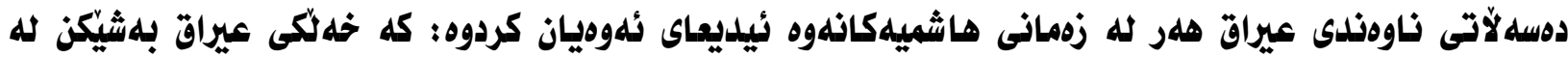

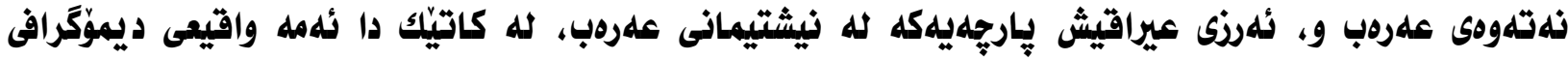

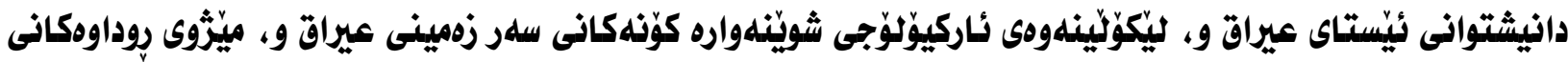

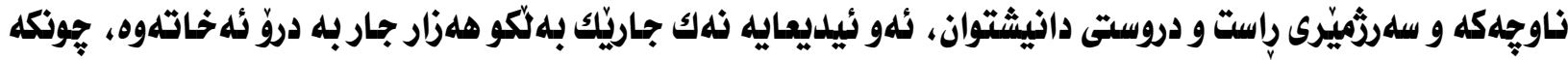

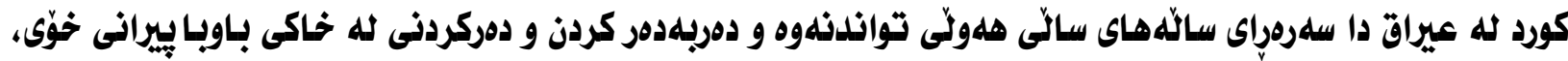

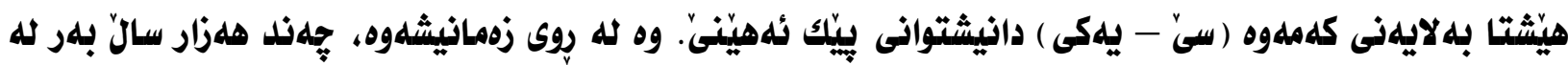

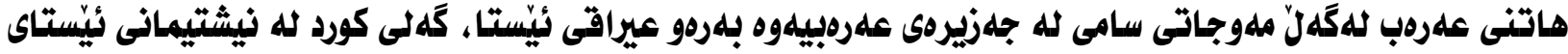

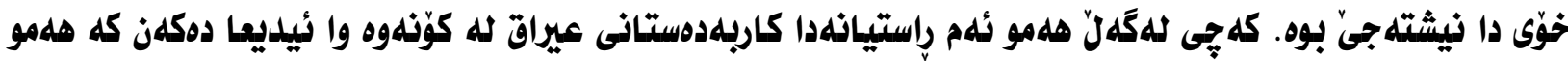

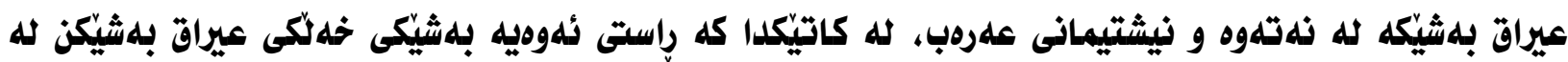

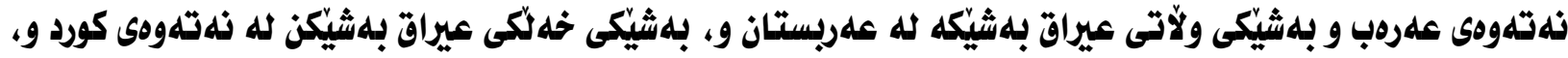

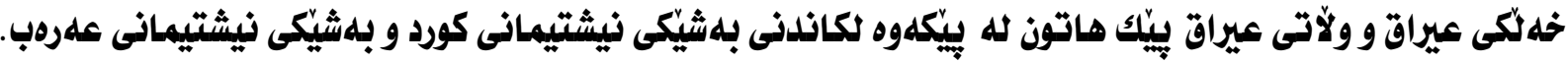

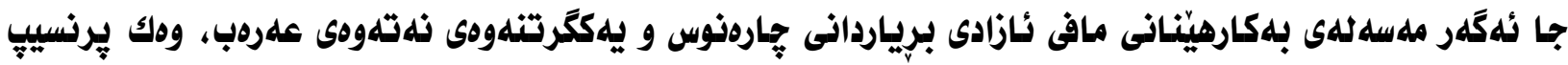

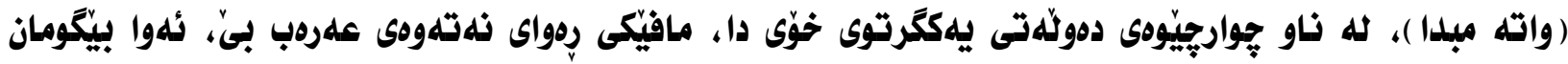

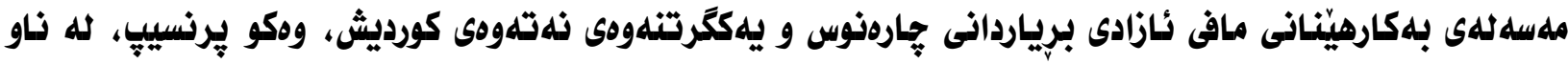

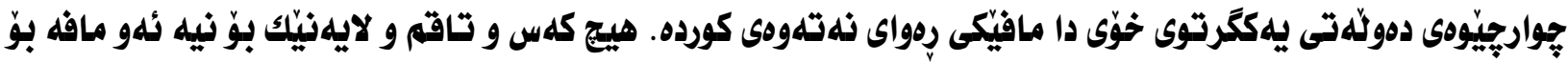

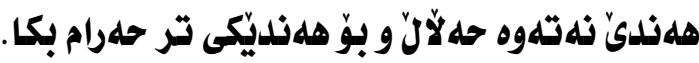

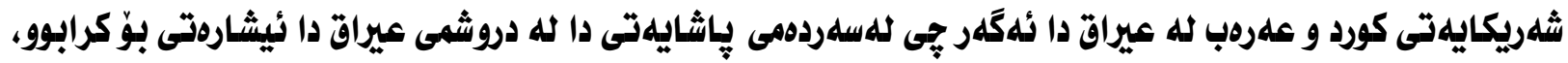
له دواييتردا له شؤرشى عاى تهموزدا هلهم له دهستورى مورقهلت دا شهريكايلهى كورد و عهرهب لله عيراق دا و، هلم له له

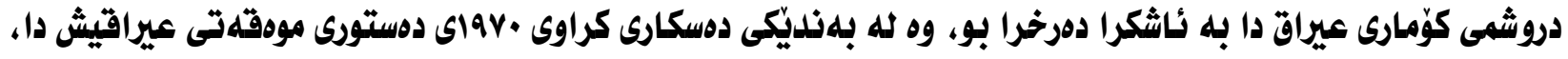

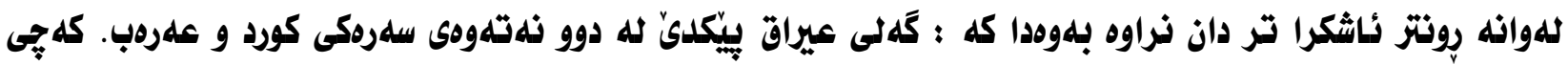

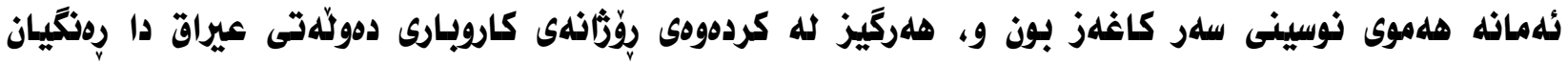

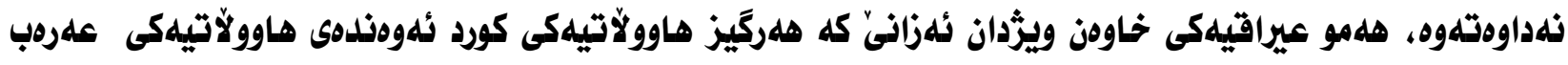

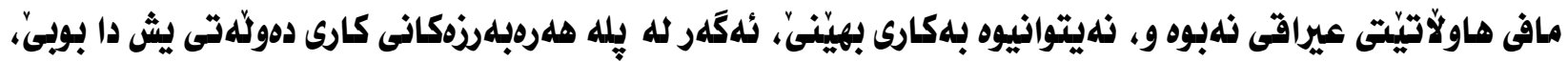

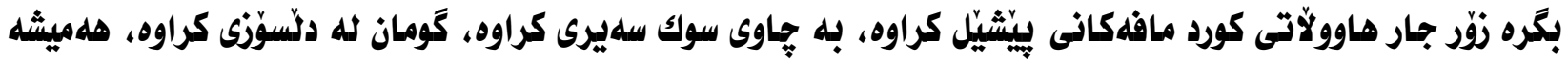

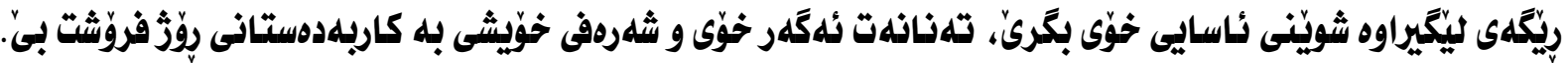

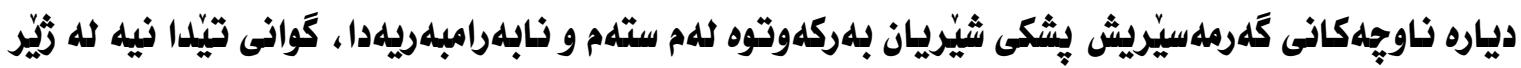

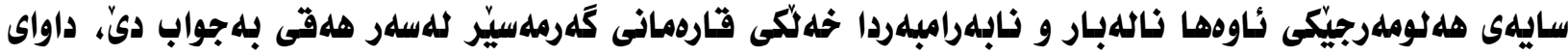

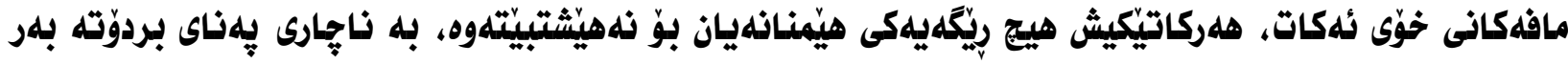

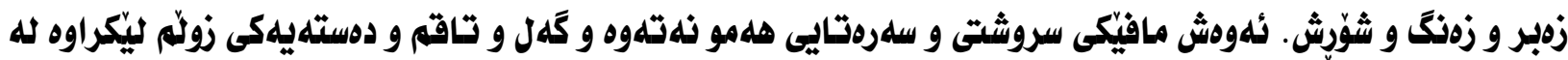




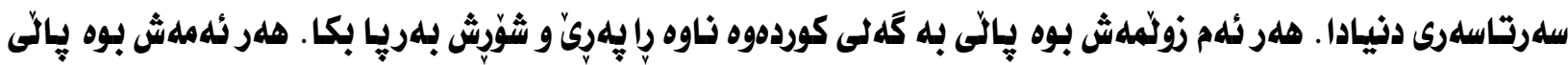

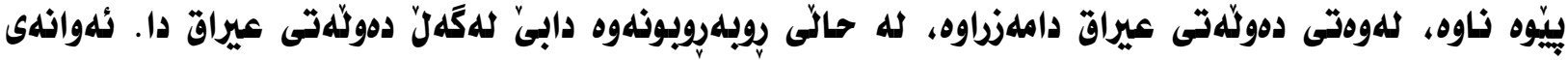

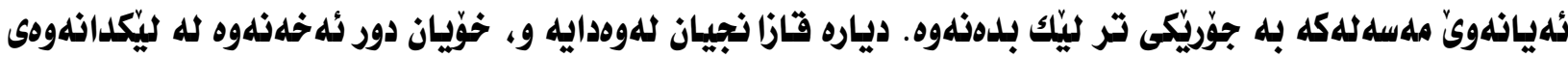
عيلمى روداوه سياسى و كوّمهلاّيليهى و ئابوريهكانى ... زيّانى ميللهتى عيراق.

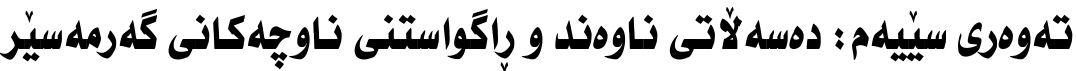

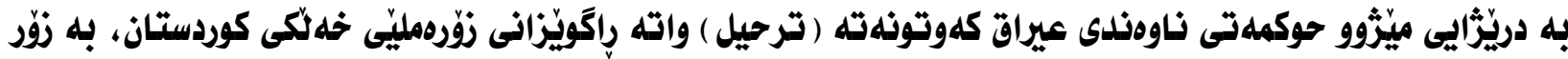

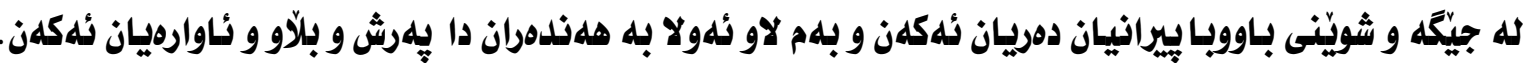

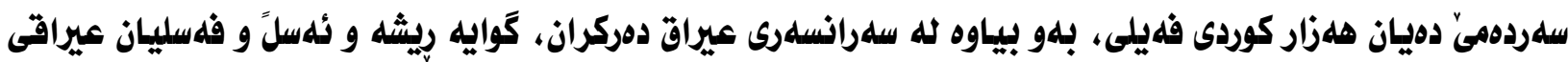

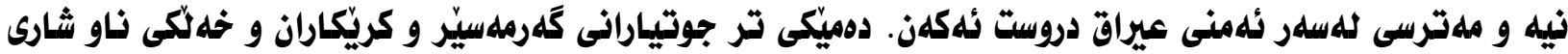

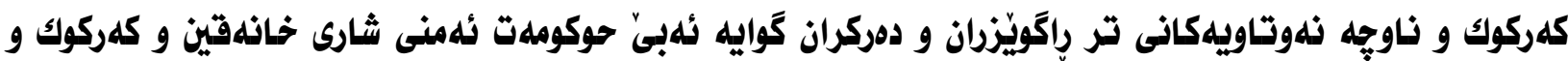
ناوجه نهوتاويهكانى بياريّزيّ.

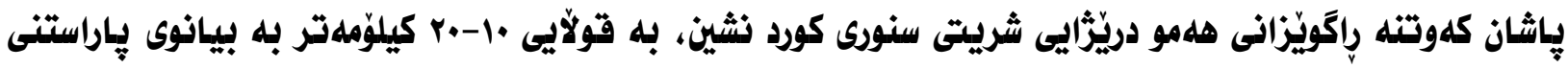
ئهمنى عيراق له تهماع و دهست دريّرى بيّكانه.

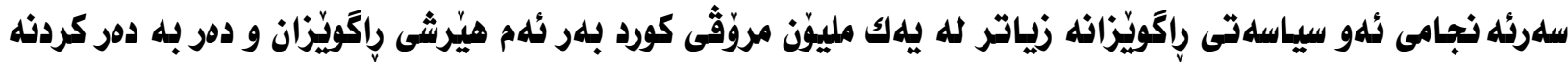

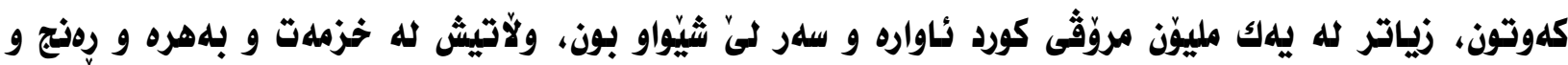
ماندوبونيان مه حروم بو.

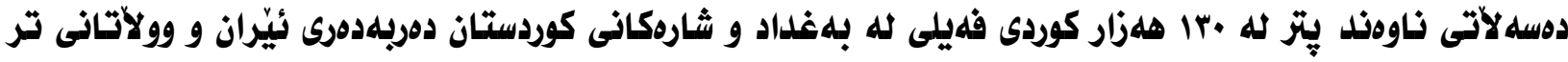

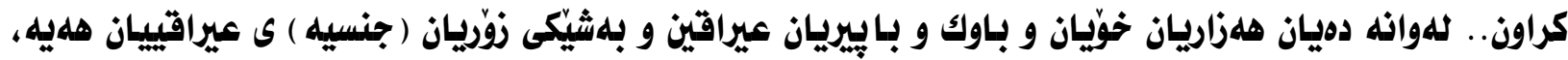

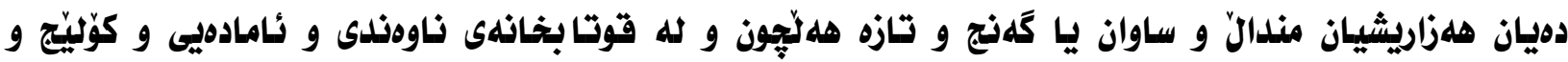

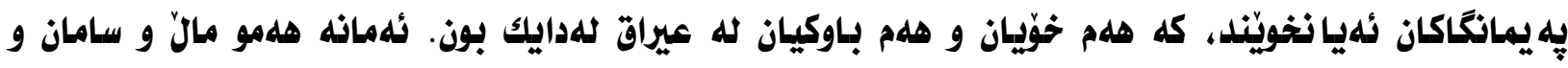

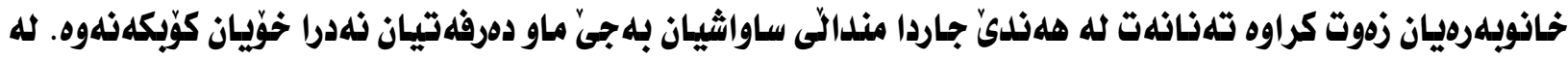

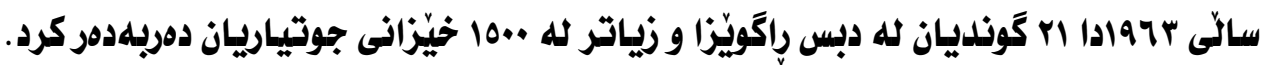

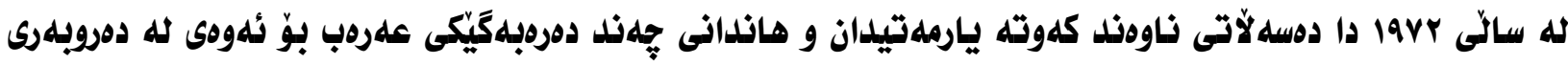

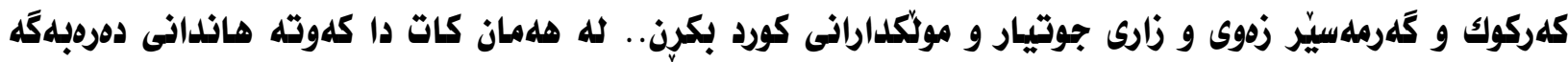

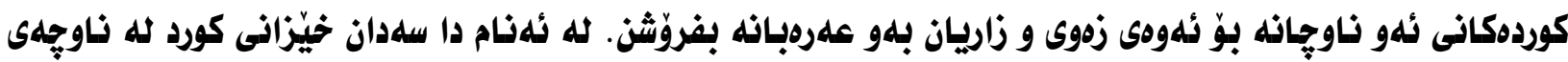

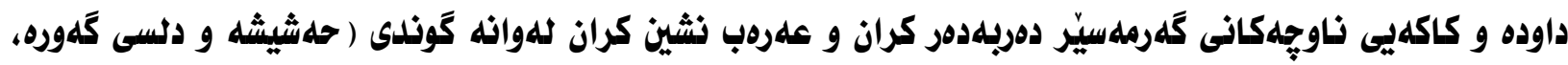

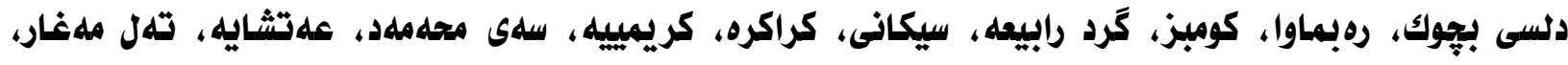

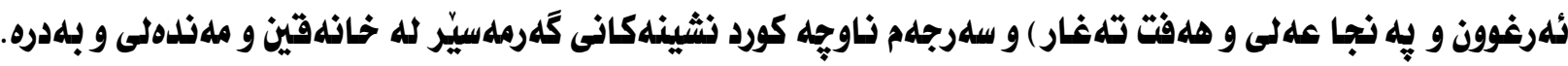

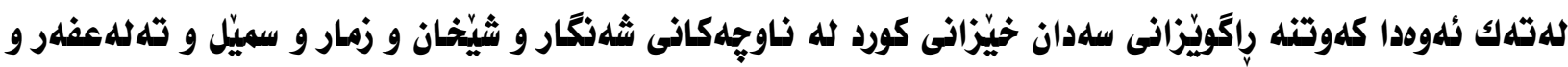

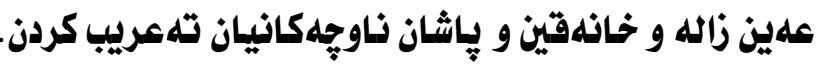

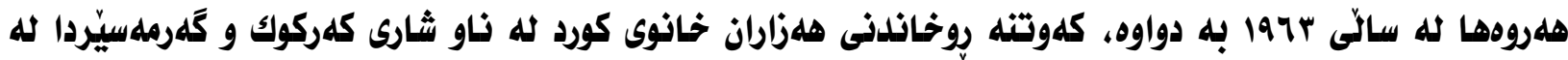

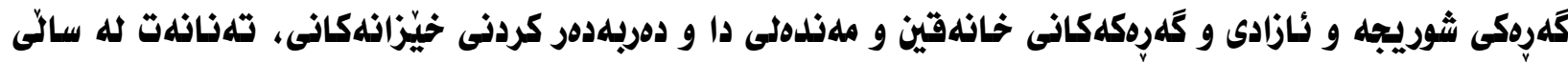




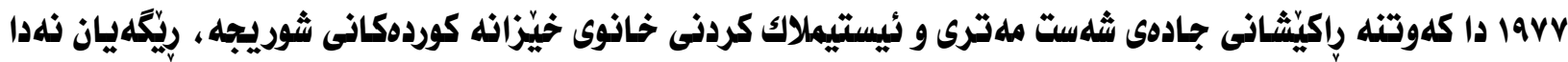

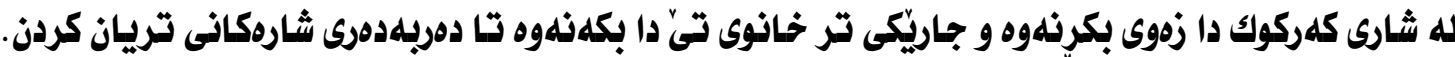

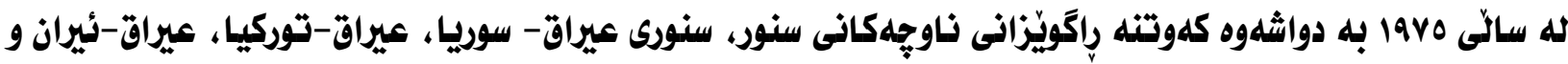

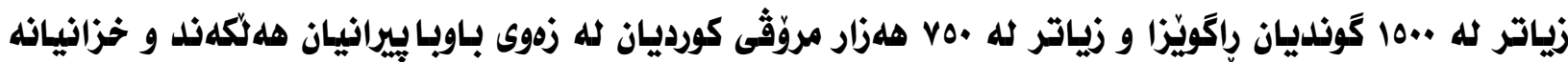

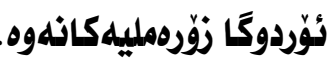

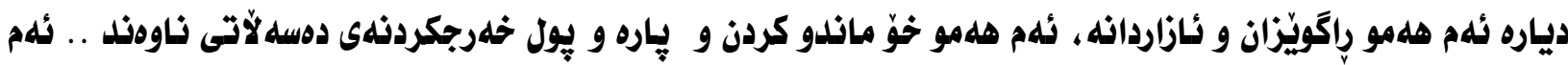

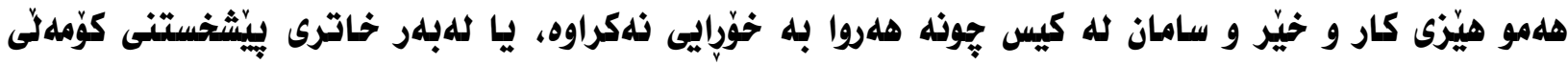
كورددوارى نلهبوه.

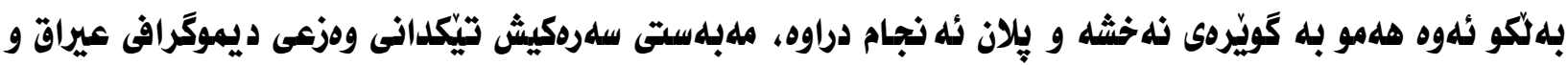

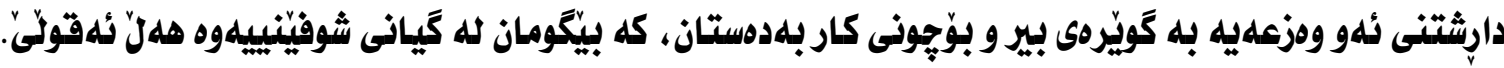

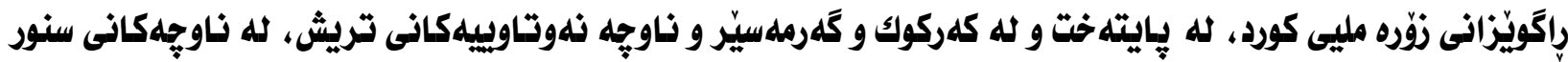

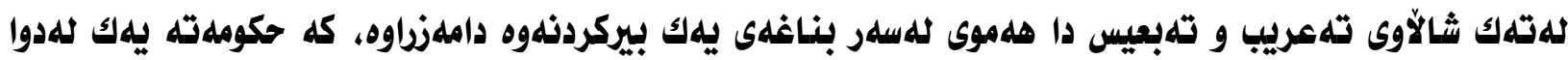

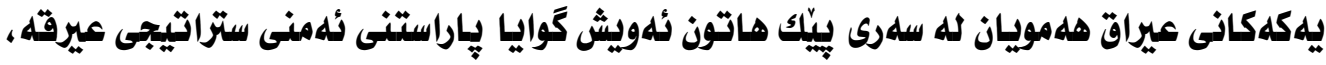

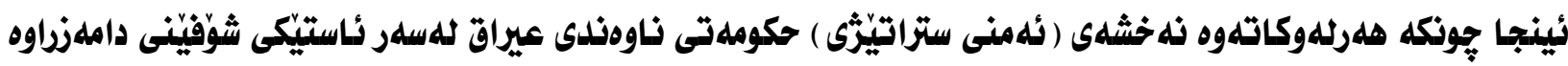

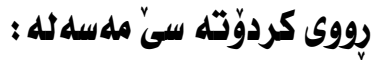

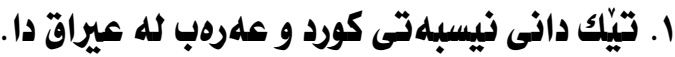

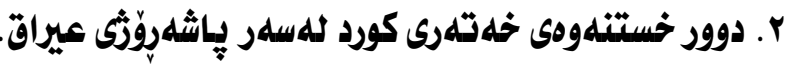
r. بيكلدانى قولايى ستراتيجى جولآنهوهى كورد.

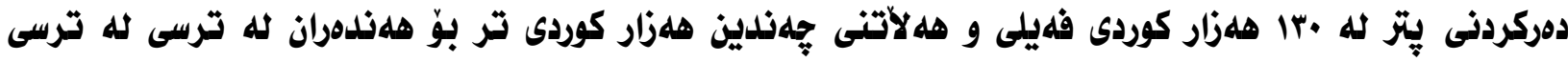

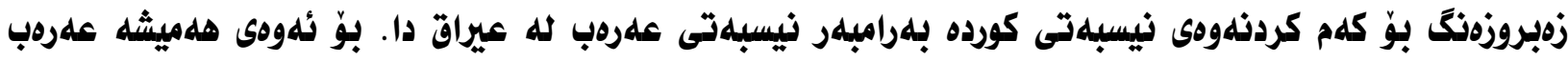

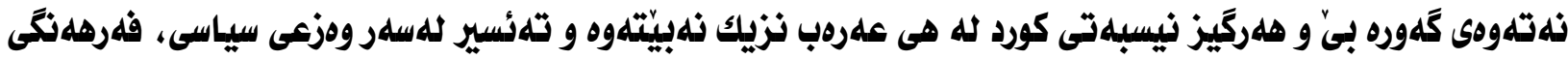

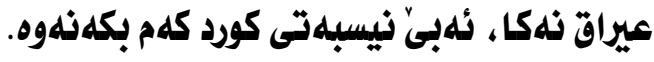

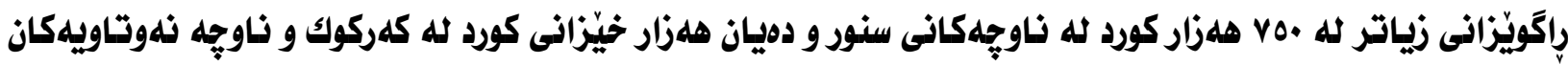

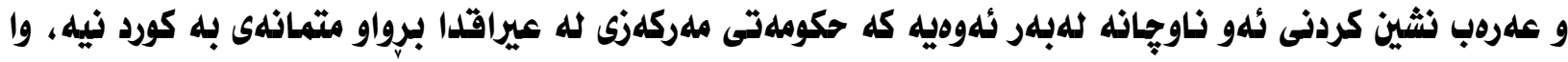

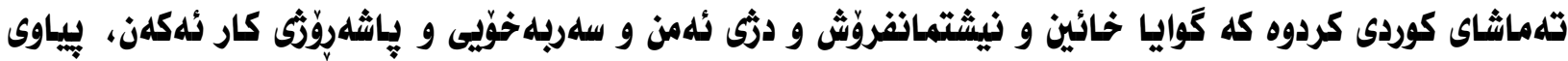

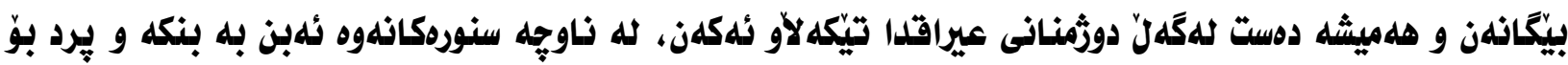

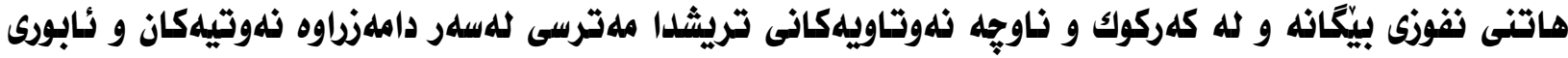

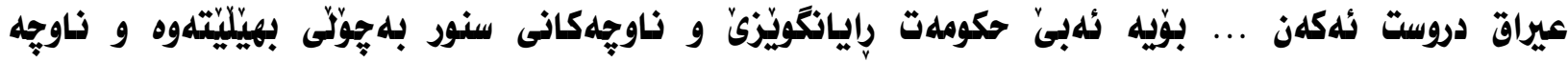

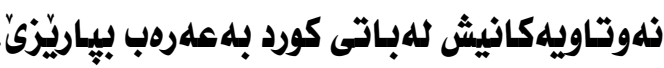

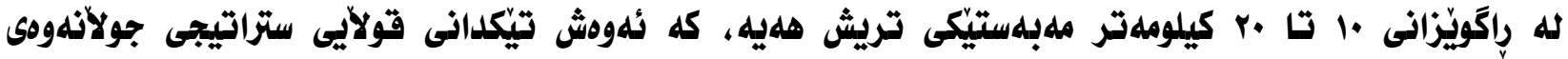

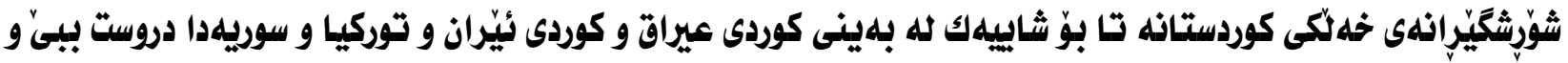

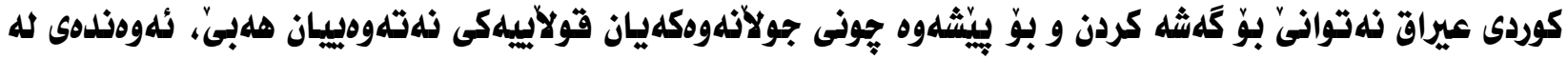




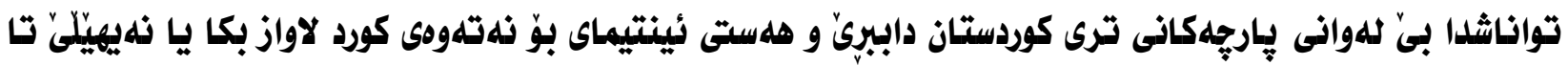

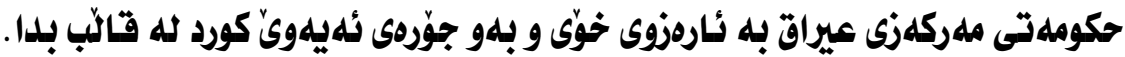

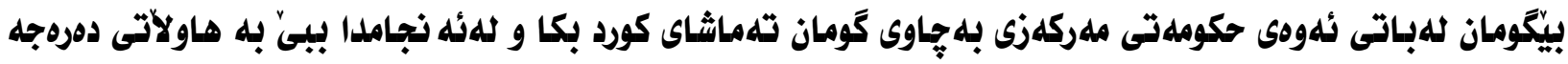

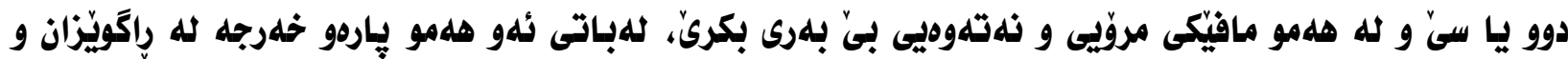

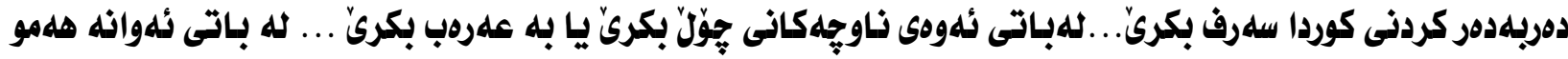

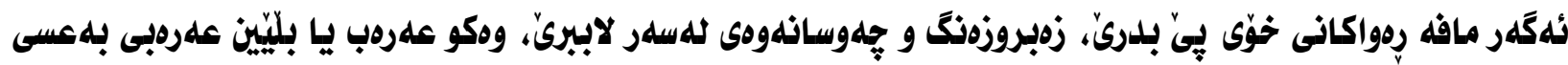

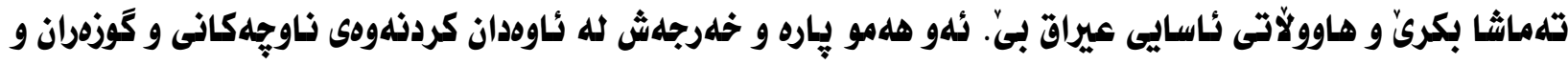

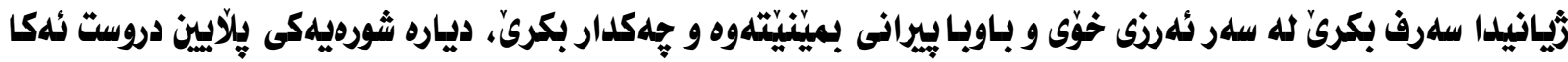

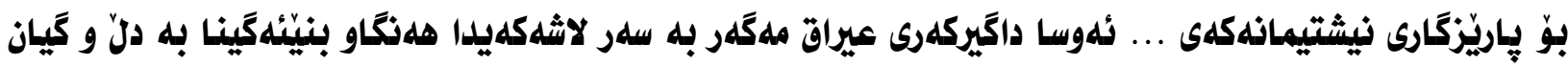

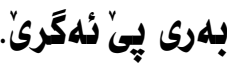

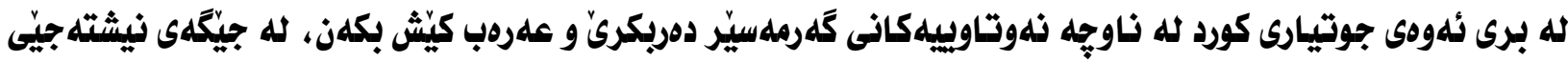

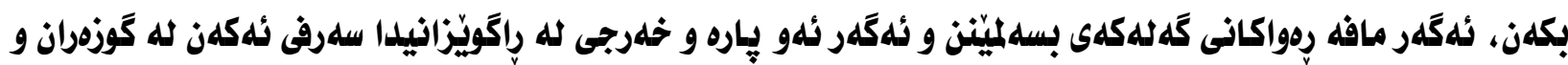

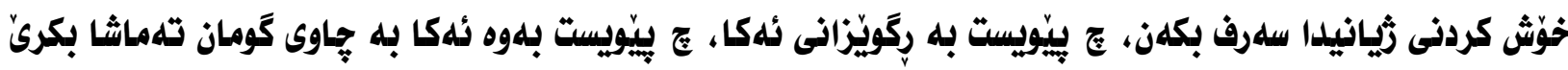

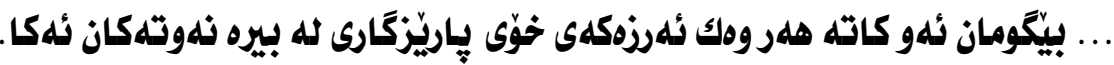

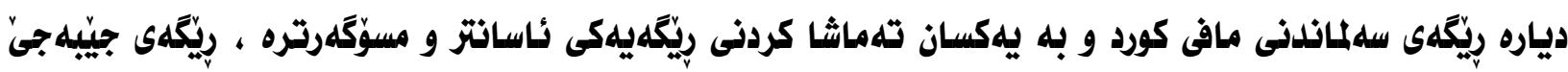

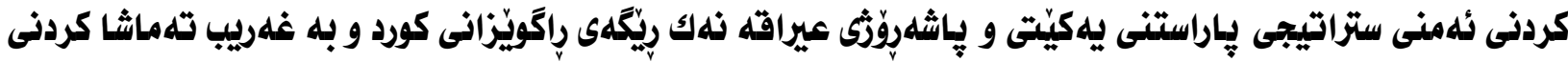

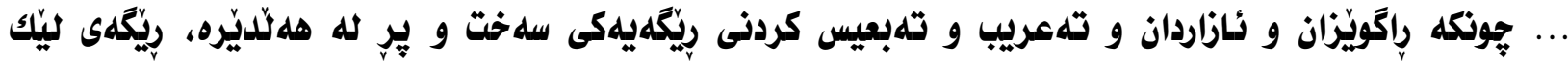

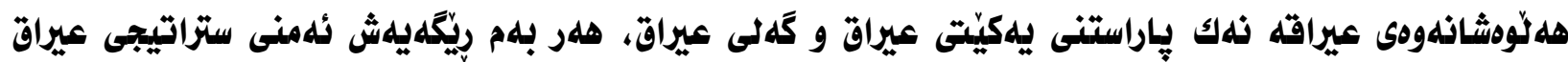
ئهكلوويته ملترسيلوه.

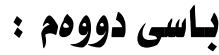

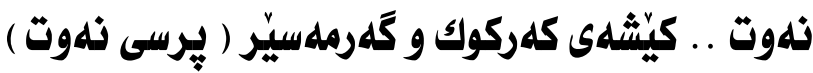

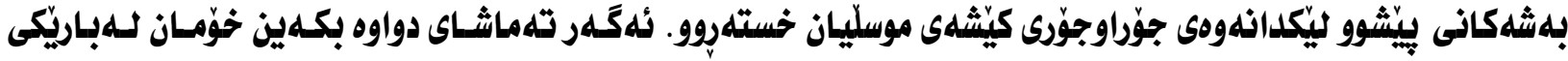

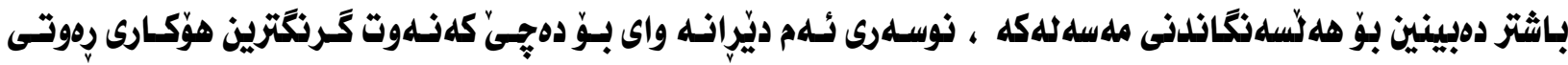

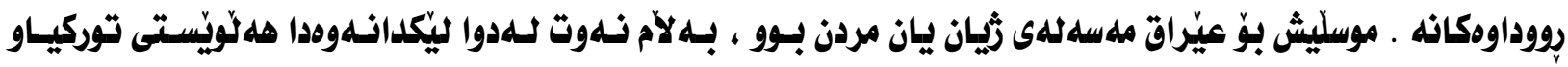

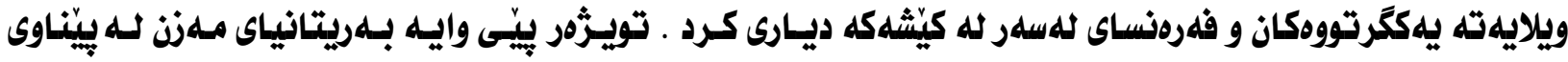

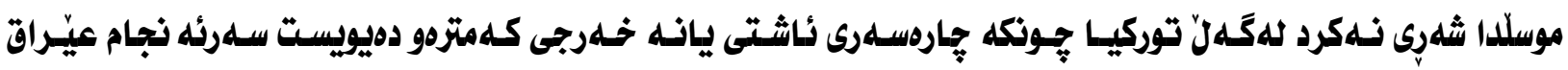

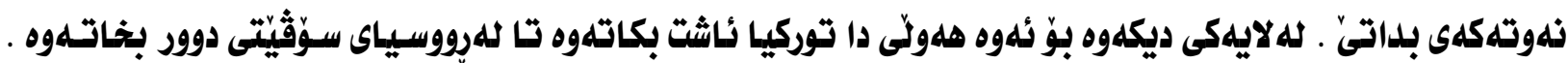

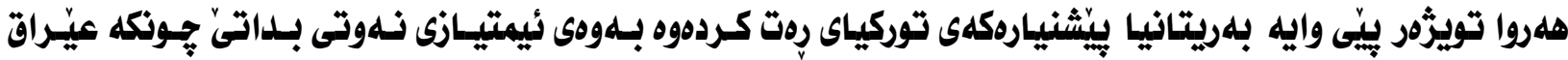

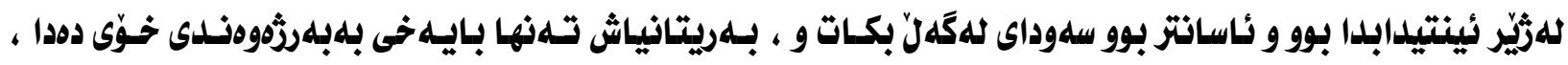

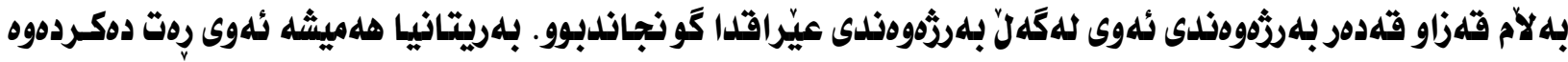

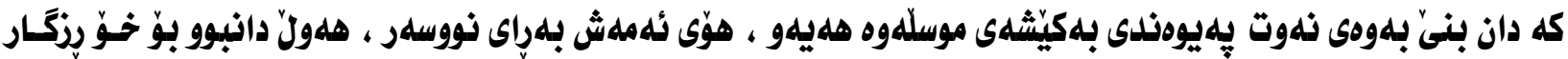




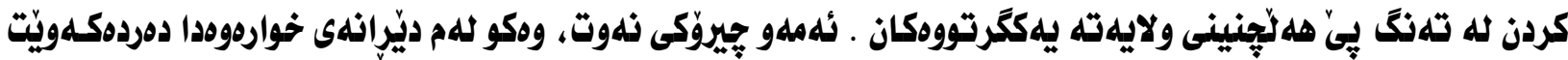

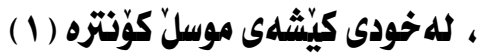

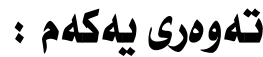

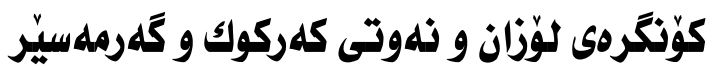

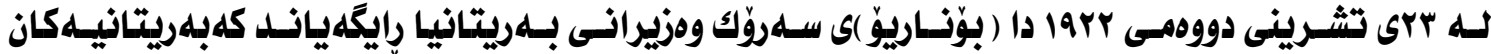

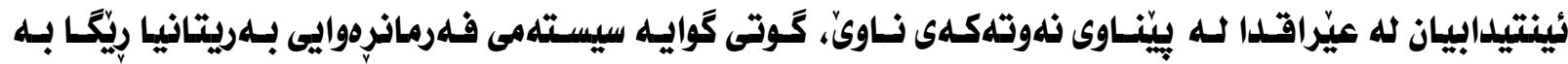

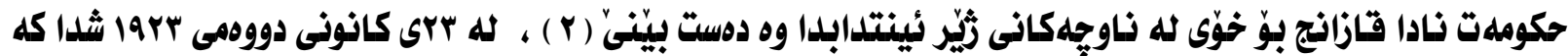

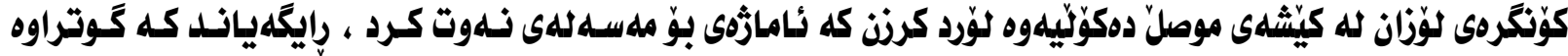

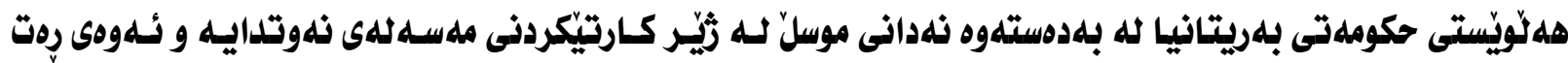

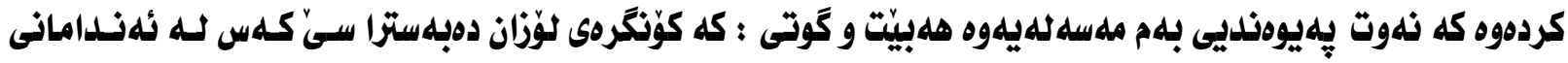

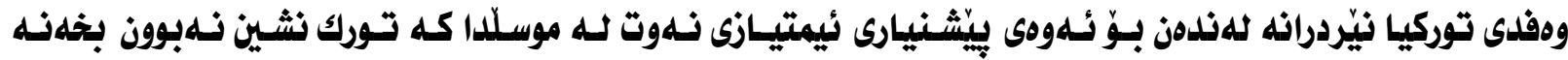

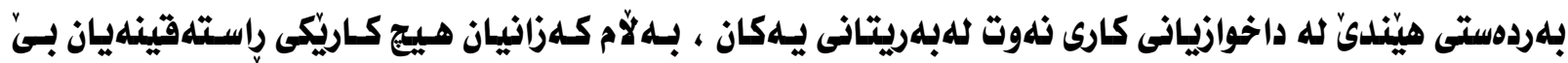

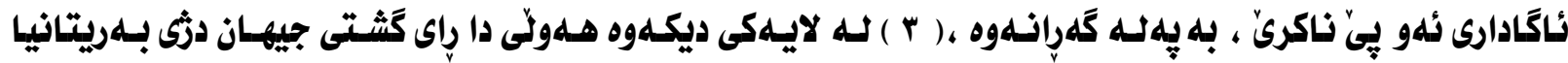

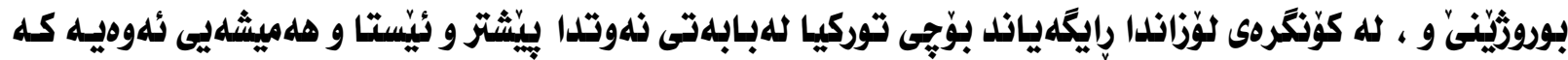

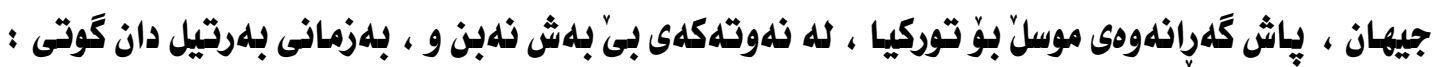

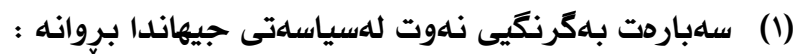

THE Oil Trusts and Auglo- American Relations ( New York, 1924) : Louis Fischer , Oil imperialism ( New York, 1926) Anton Mohr, The Oil War ( New York, 1926): Lud Well Denny We Fight for oil ( New York, 1935) : Parker T.

Moon, imperialism and World polities (New York, 1939)

(2)Quoted inDavenport and cooke,op .cit . 150.

(3) Cmd. 1814 .p, 360.

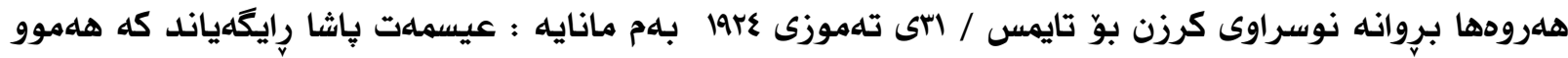

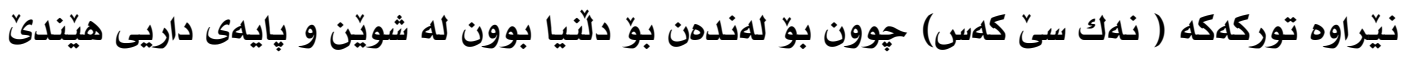
له تاقمانهى داخوازى ئيمتياز له نهوتى موسلّدا ددكهن . 


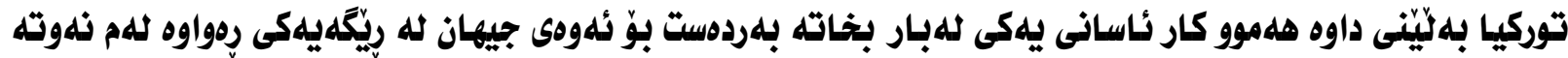

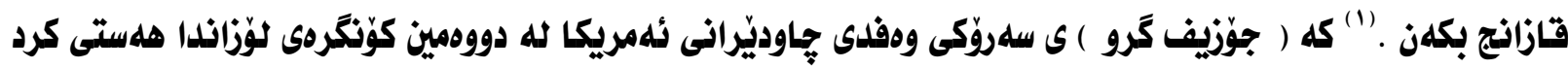

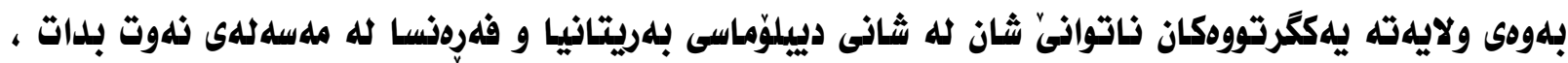

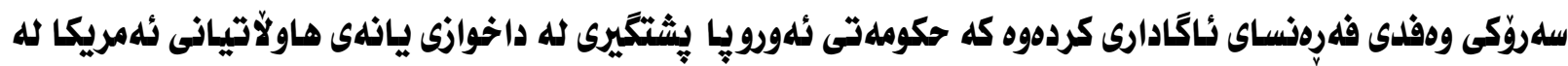

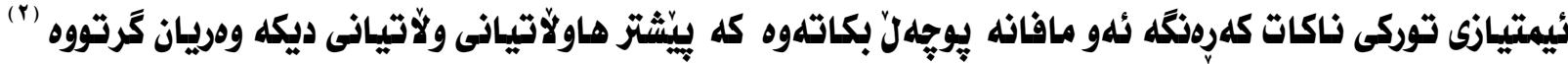

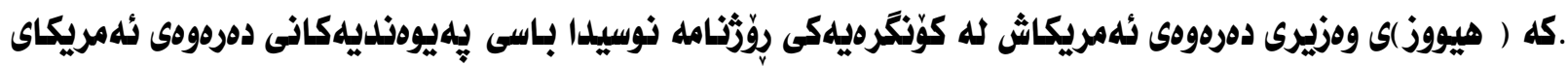

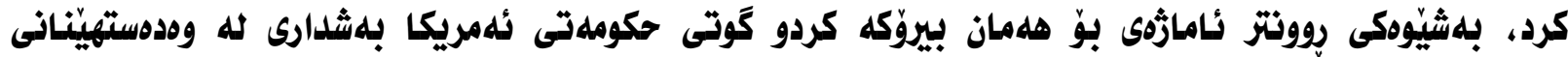

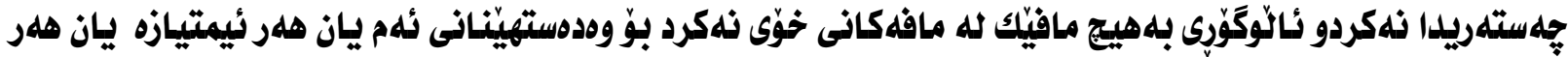

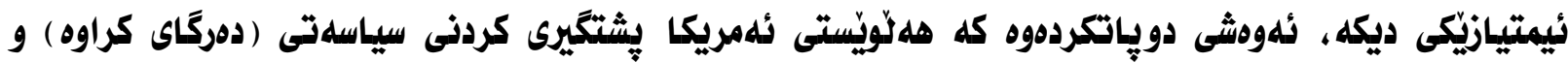

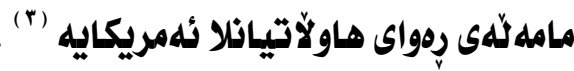

تلهوهرى دووهم :

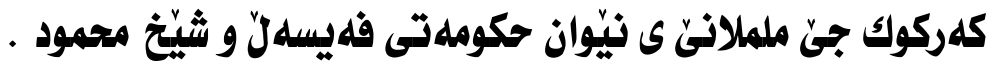

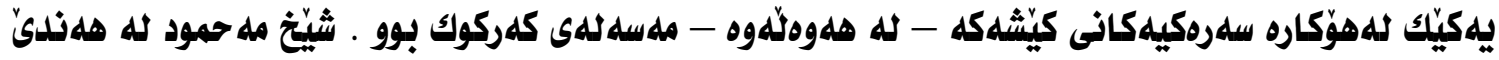

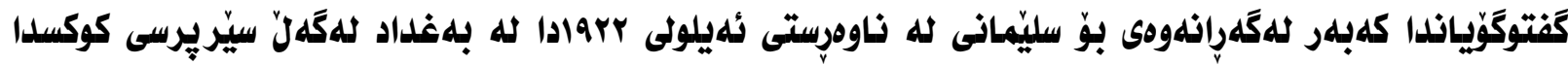

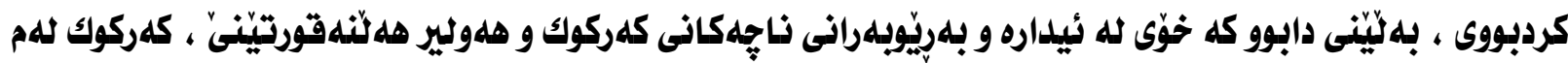

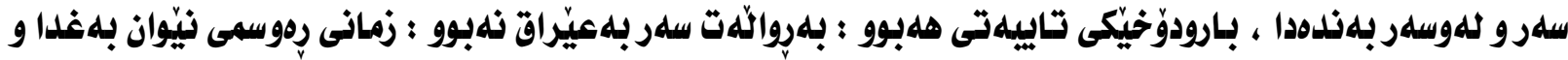

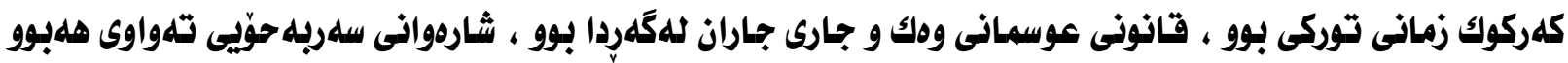

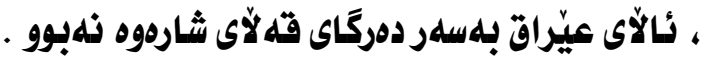

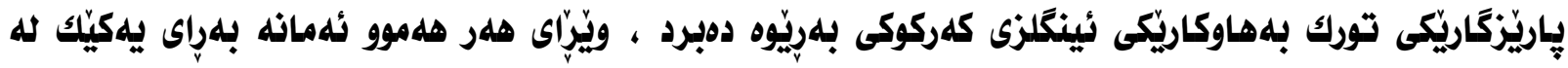

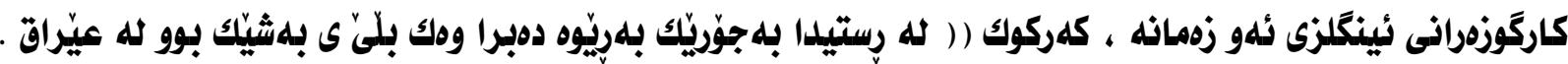

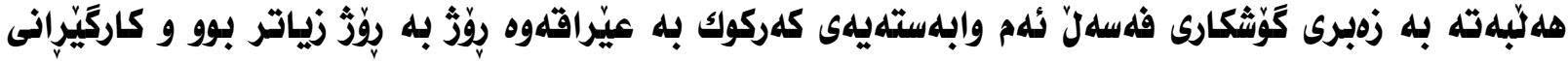

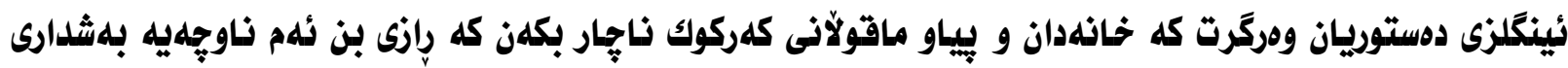

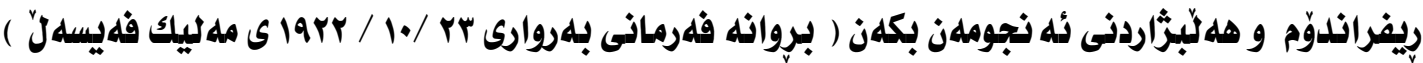

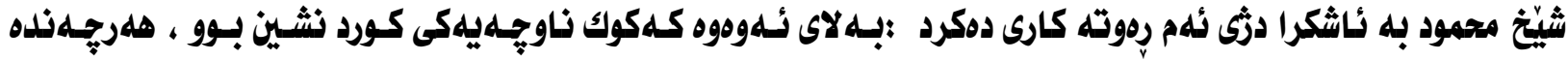

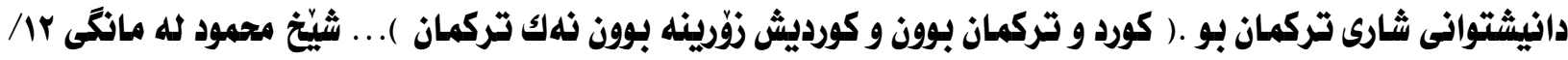

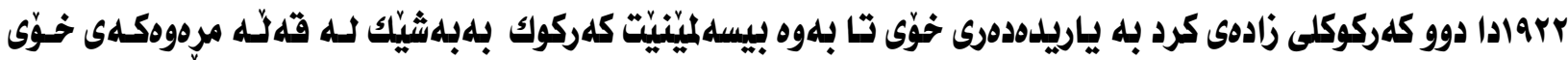

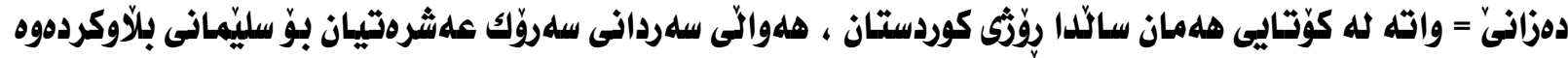

(1) Cmd. 1814 .p,397.

(2) The new york Times , janury 24, 1924.

(3) The new york Times , janury 24, 1924.

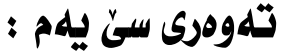


كوردستانى بوونى كلركوك له بله لكّنامه عهربلى و بيانى يهكاندا .

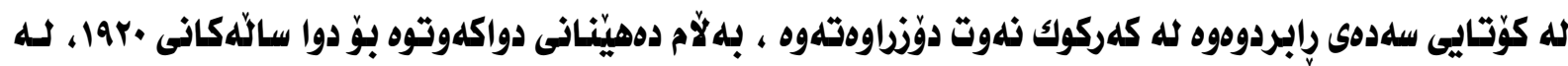

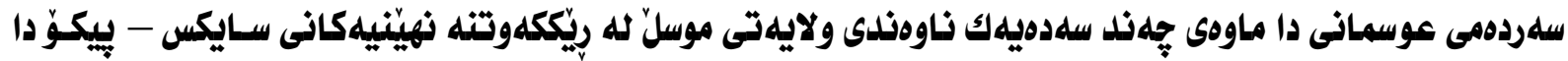

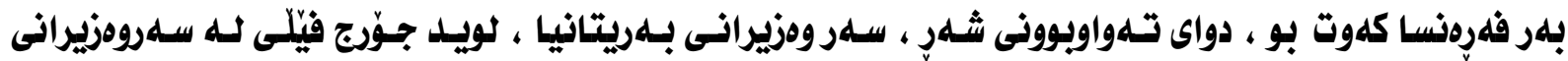

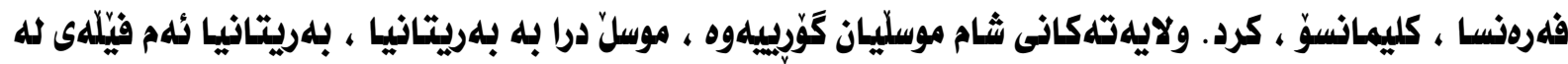

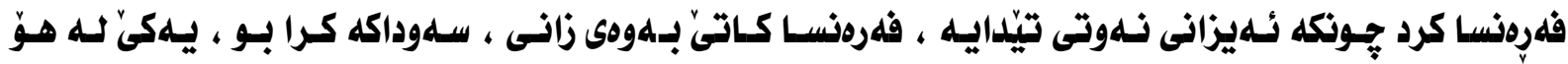

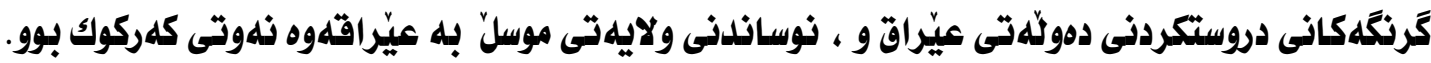

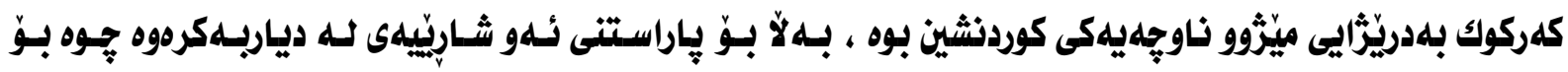

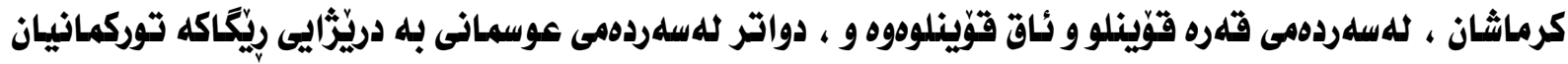

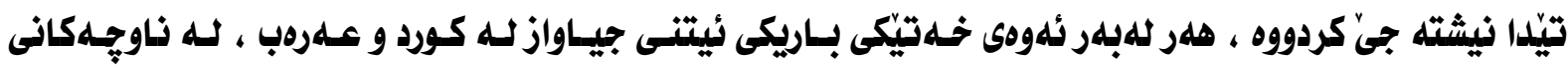

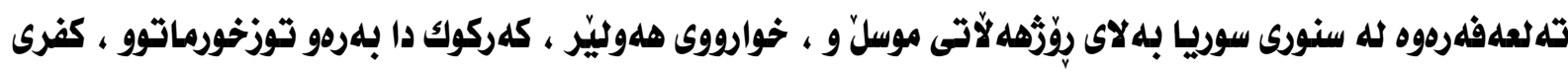

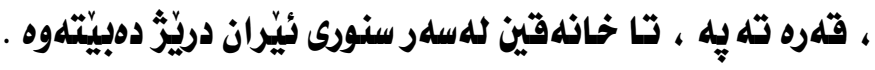

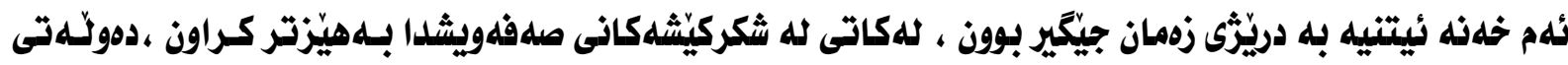

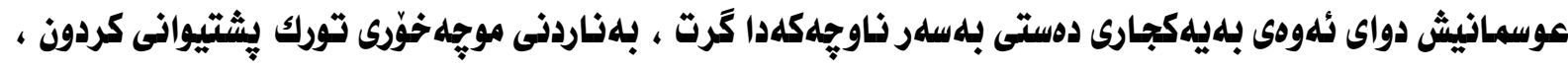

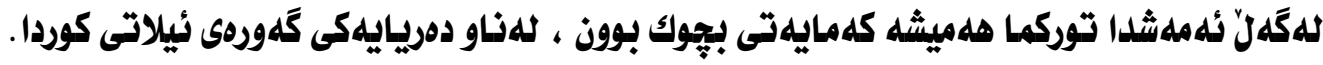

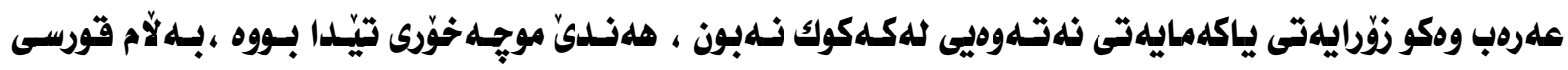

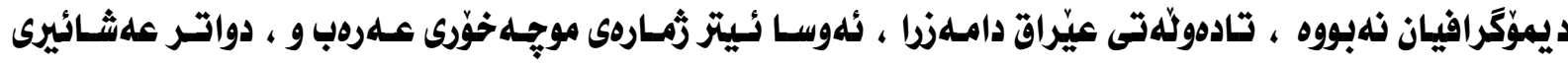

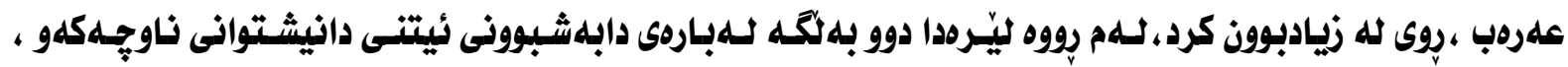

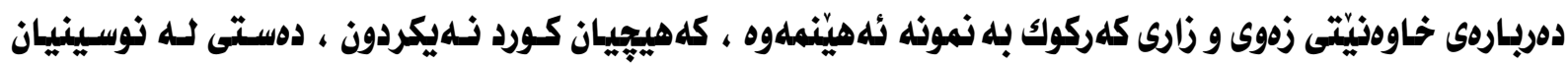
دانهبووه.

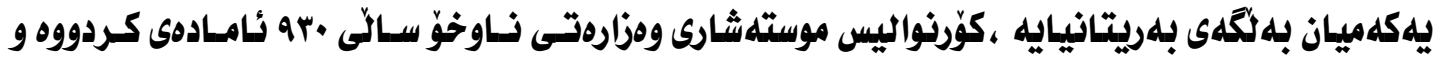

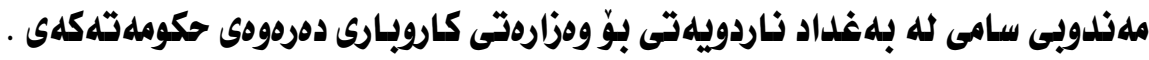

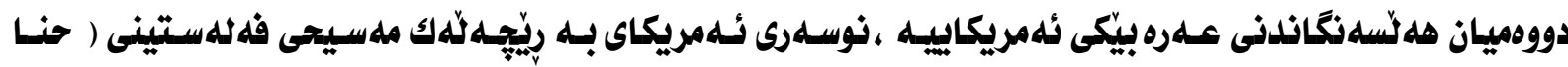

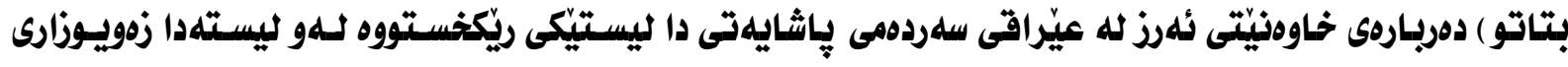

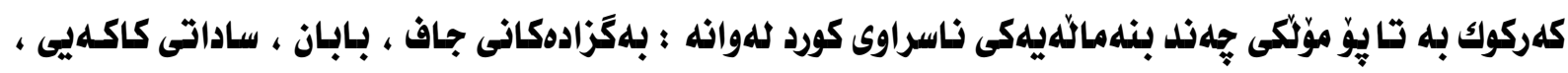

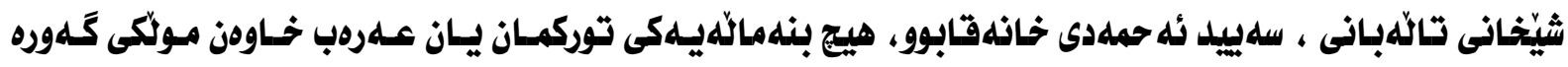

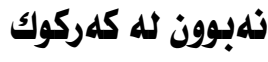

دهره ذجام: 


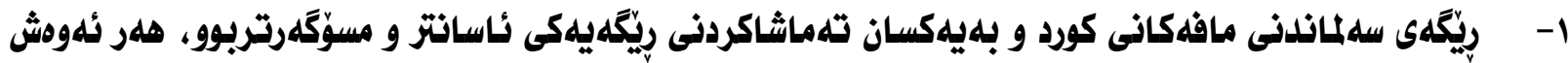

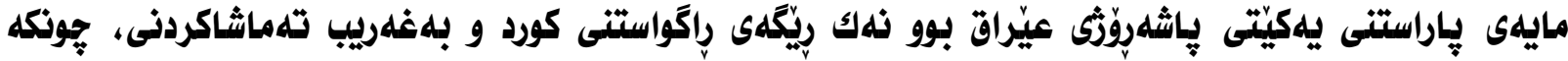

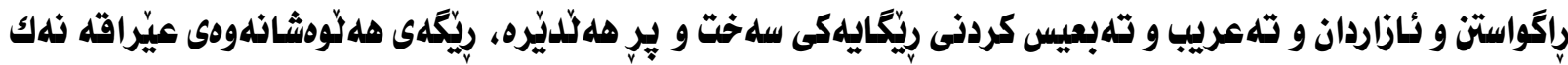

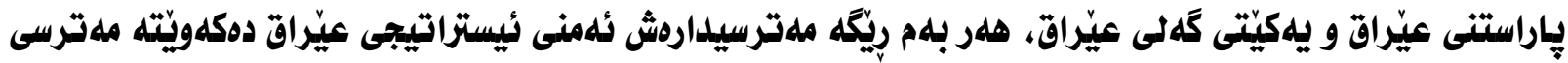

$.09 d$

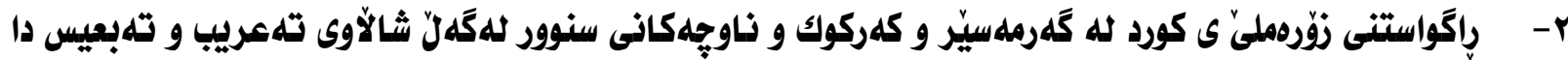

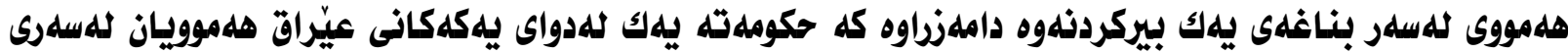

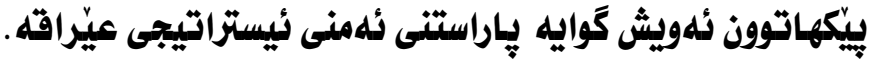

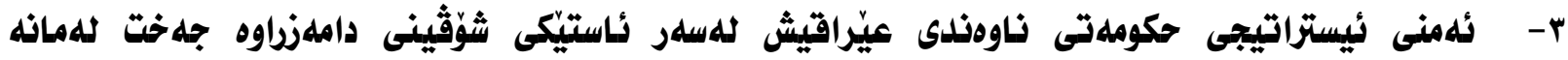
دوكاتلووه:-

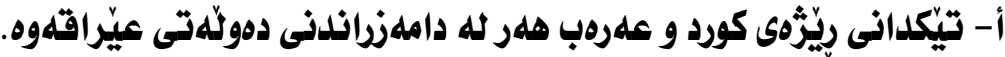

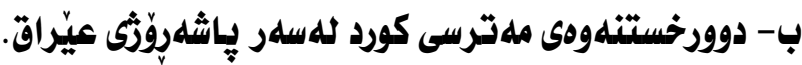
ج- تيكلدانى قولاًيى ستراتيجى جولاًانهوهى كورد.

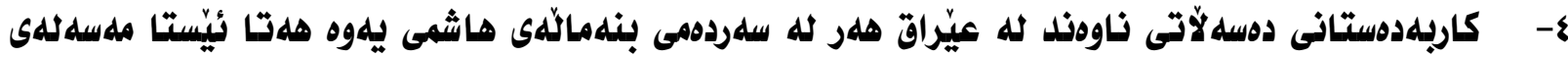

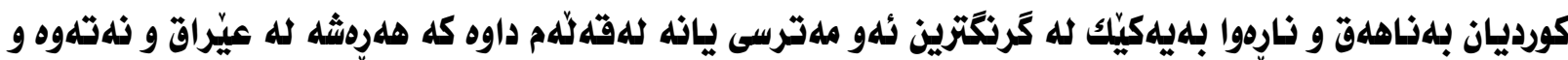
نيشتمانى علرهب دوكات.

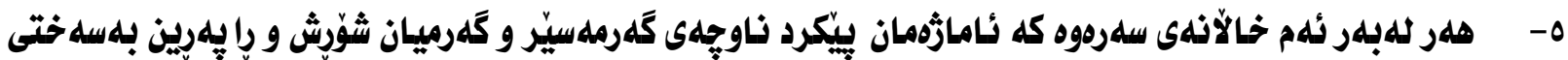

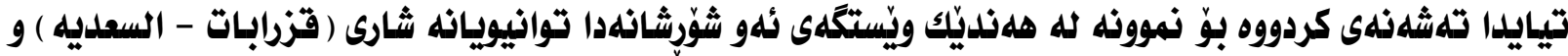

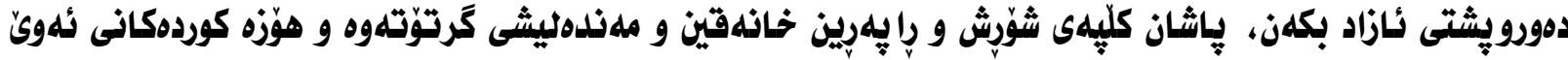

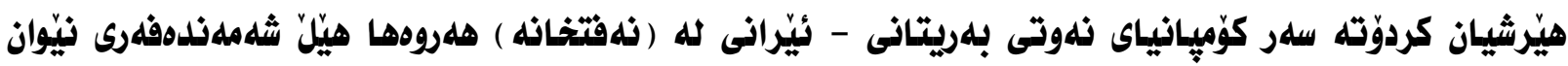

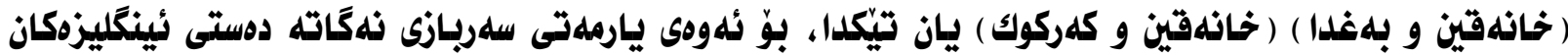

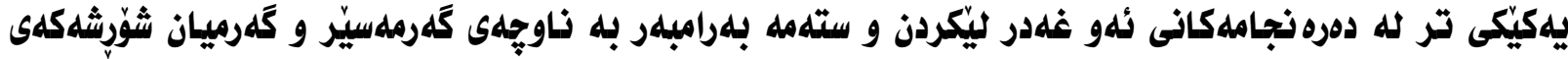

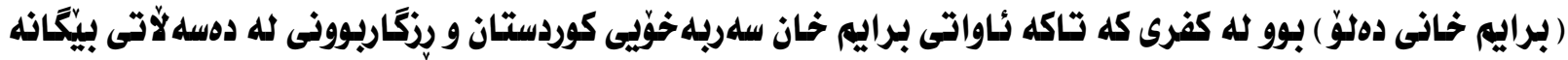
و ن احلهزان بوو.

سلمرجاوهكاز 


\section{سلهرجاوه كورديهكاز}

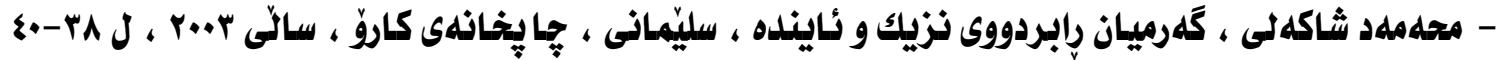

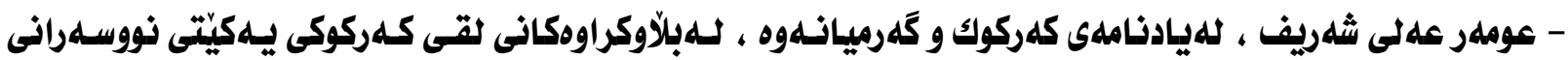

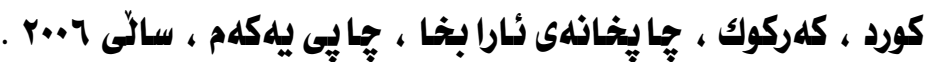

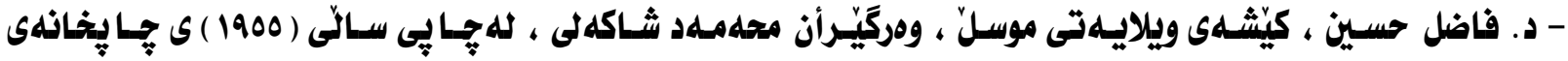

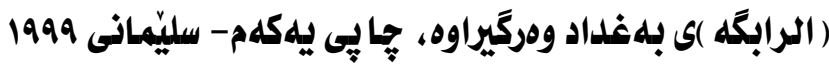

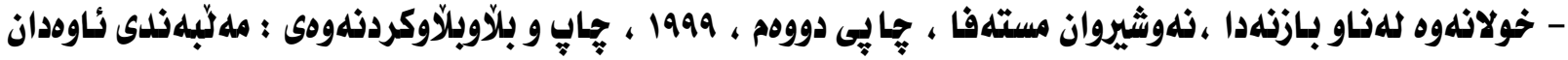

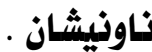
Awadani nehringstr 14059 Berlin

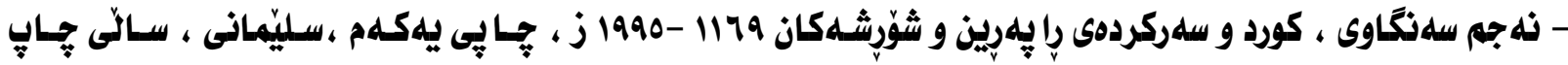
r. r. r

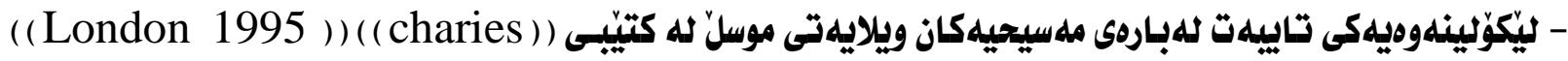
Harry luke.Mosul and Its Minorities

- L.M Fanning, oil in the word war (new York 1922)

- F. oelaise, oil its influence on polities (London ,1922)

- The New York Time April 24/1926 Foreign policy Association information service 11,p.77.

-The Times , March ,18, 1925

- Edward Mead Earie The ((The Turkish Petroleum company)) in The political Science Quarterly P,277- 278.

- W.R.Hay ,Two years in Kurdistan (1921). E.B. Soane To Mesopotamia and Kurdistan in disguise (1922)

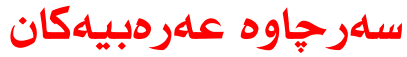

طـه الهاشمى ،مزكرات طـه الهاشمي ، 1919 - 19\& ، جا ، بـيروت 1971 نـورى عبدالحميـد خليـل ، التـأريخ

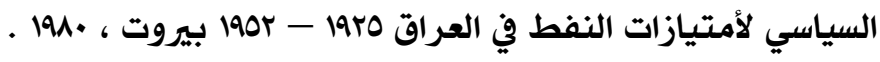

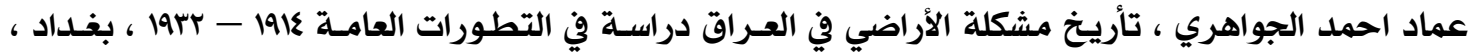
. 19Y1

الحسينى ، تأريخ العراق السياسي الحديث ، الجزء الثاني ص 1.1 ـ1.1 ( قرارات مجلس الوزراء الصادرة في

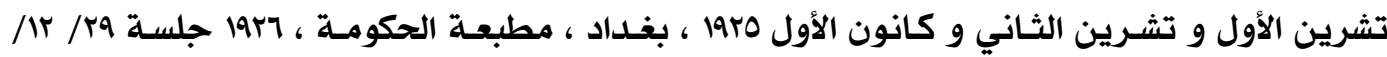

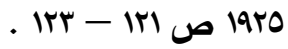




\section{Abstract}

In this research: I want to point out Kirkuk in the seeker documents and the American, British and Ottoman empire about Kirkuk and how they found oil in this city in the twenties of the last century was a barrier and an obstacle when it came to build a Kurdish government, at the same time, one of the greatest reasons to make Iraq's new Government.

The people of the area demanded an independent government lead by " Shex Mahomood Malik " also the capital could be Sulaimani or Musil but unfortunately even when they united the state with Iraq they didn't negotiate with its people when they wanted an independent state .

After the English attacked Iraq and took over the city (Basra ) in the Spring of 1917 ,after that the Capital (Baghdad) and the rise and the Progress of their army towards the north to take over the Capital of the state which was (musil) . after they conquest (kirkuk) in September 1918 they were only a few miles away from taking over the state (musil), ( Modros) contract, which was signed between the English and the Turkish in the same year it said that the English Should not go further by Inundating States, In this Situation a problem appeared called (( the problem of musil state)) between four sides (( The English smelled the oil and planned to take over the state by themselves, and for that matter they bargained with the French and then manipulated them, but when the French knew all about it, it was too late and the bargain was already done, (( also the French de minded the state because the state was given to them as it said (syxe - picko)) in 1916 . ((the Turkish wended the state and as they said Kurds and Turks were one nation, so they said it was their right to take over the state mean while they called the Kurdish clan chiefs (( Turks)) . They announced that Musil sates Economic advantage and social connections were similar to ardors, but of course none of these Excuses made any sense because all of those different sides which were mentioned before, never had any right on the state but the native inhabitants of the state owned that right who were most Kurds either were ( Muslims or Christian or Shabak or Arabs Tursk or Ezidis ) they were the only people who had the right to decide their state's destination. 